\title{
MEMÓRIAS, DISPUTAS DE SENTIDO E TRANSFORMAÇÕES SOCIAIS: AS ESTRATÉGIAS E AS TRAJETÓRIAS DOS EX-TRABALHADORES DA VARIG DEZ ANOS APÓS SUA VENDA
}

Madhiana Valéria Almeida Rodrigues $ه$ 


\section{RESUMO}

O artigo trata dos fenômenos de transformação ocorridos na trajetória dos ex-funcionários da VARIG, tanto os aposentados quanto os que ainda estavam na ativa quando do fechamento da empresa, atingindo sistemas de representações e relações anteriormente construídas. Trata-se de um caso paradigmático na história da aviação civil no país. Seguindo a metodologia etnográfica, foram realizadas quinze entrevistas não estruturadas e pesquisa em mídias. Argumenta-se que, diante das necessidades e das disputas de sentido do presente, a memória e a função fantástica do imaginário são utilizadas como ferramentas estratégicas de resistência e de transformação, sobretudo relacionadas às novas formas de sociabilidade e de organização. Por fim, analisa-se a situação contemporânea do grupo que vive "exposto à ameaça do esquecido" (Ricoeur 2007:18). Conclui-se que o esquecimento pode revelar indícios de uma interpretação vulnerável dos acontecimentos e de uma atitude ideológica geral diante da "naturalização" das perdas de direitos, inclusive trabalhistas, em curso no Estado.

Palavras-chave: trabalho; perda de direitos; dimensão simbólica; alteridade; transporte aéreo.

\section{MEMORIES, DISPUTES OF MEANING AND SOCIAL TRANSFORMATIONS: THE STRATEGIES AND TRAJECTORIES OF THE FORMER WORKERS OF VARIG TEN YEARS AFTER THEIR SALE}

\section{ABSTRACT}

This article deals with the transformation phenomena that occurred in the trajectory of the former VARIG employees, both retired and those who were still active in its closing process, reaching previously constructed systems of representation and relations. This is a paradigmatic case in the history of civil aviation in the country. Following the ethnographic methodology, fifteen unstructured interviews and media research were conducted. It is argued that in the face of the needs and disputes of meaning of the present, the memory and the fantastic function of the imaginary are used as strategic tools of resistance and transformation, especially related to the new forms of sociability and organization. Finally, the contemporary situation of the group that lives "exposed to the threat of the forgotten" is analyzed (Ricoeur, 2007: 18). We concluded that forgetfulness may reveal signs of a vulnerable interpretation of events and of a general ideological attitude towards "naturalization" of the loss of rights, including labor rights, in progress in the country.

Keywords: work; loss of rights; symbolic

dimension; alterity, air transport.

\section{MÉMOIRES, CONFLITS DE SENS ET TRANSFORMATIONS SOCIALES: STRATÉGIES ET TRAJECTOIRES DES EX-TRAVAILLEURS DE VARIG DIX ANS APRÈS SA VENTE}

RESUME
Cet article traite des phénomènes de transformation survenus dans la trajectoire des anciens employés de VARIG, retraités et restant actifs dans son processus de fermeture, atteignant des systèmes de représentation et de relations précédemment construits. Il s'agit d'un cas paradigmatique dans l'histoire de l'aviation civile du pays. Suivant la méthodologie ethnographique, quinze entretiens non structurés ont été réalisés, ainsi que des recherches sur des sites Web et des journaux. Nous proposons que, face aux besoins et aux conflits de sens du temps présent, la mémoire et la fonction fantastique de l'imaginaire sont utilisées comme des outils stratégiques de résistance et de transformation. Ils concernent avant tout de nouvelles formes de sociabilité et d'organisation. Enfin, nous analysons la situation actuelle du groupe qui vit "exposé à la menace de l'oubli" (Ricoeur 2007:18), et concluons que l'oubli peut révéler des signes d'une interprétation vulnérable des événements et d'une attitude idéologique générale à l'égard de la "naturalisation" des pertes de droits, y compris des droits du travail, en cours dans le pays.

Mots-clés: travail; perte de droits; dimension symbolique; altérité, transport aérien. 


\section{INTRODUÇÃO}

Todos aqueles que se inclinaram de maneira antropológica, isto é, a um só tempo com humildade de espírito e largueza de horizonte poético, sobre o campo do imaginário, estão de acordo em reconhecer à imaginação [...] esse poder realmente metafísico de erigir suas obras contra o apodrecimento da Morte e o Destino (Gilbert Durand).

As reflexões apresentadas aqui expressam parte do esforço que venho desenvolvendo no sentido de compreender, à luz da antropologia, temáticas concernentes ao universo dos ex-trabalhadores da aviação civil, suas trajetórias e seus projetos para a vida, após o fechamento daquela que foi a maior empresa de aviação que o Brasil já teve. Tenho como foco de interesse empírico os ex-funcionários da Viação Aérea Rio-Grandense (VARIG), tanto os aposentados quanto os que ainda estavam na ativa na época de seu fechamento, em sua maioria, sediados nas cidades do Rio de Janeiro, de São Paulo e de Porto Alegre.

A ideia inicial para este artigo, portanto, veio da possibilidade de acompanhamento dos projetos de vida atuais dos ex-funcionários da VARIG, a fim de verificar como eles vão moldando sonhos, desejos, sentidos e significados do trabalho, continuidades e descontinuidades na forma de vida e nas necessidades de sustento. A análise dos dados de campo ampliou os objetivos na direção da compreensão de como essas pessoas vêm (re)significando suas experiências passadas no trabalho na VARIG e como vêm renegociando a busca pela sobrevivência, no confronto com os desafios práticos do dia a dia. A hipótese aqui levantada é de que a VARIG e o universo da aviação estiveram, e ainda estão, mergulhados em símbolos específicos, ideias e mitos, sob os quais seus exfuncionários (re)criam suas ferramentas de luta e de resistência.

$\mathrm{O}$ artigo busca traçar alguns pontos representacionais importantes do contexto e das especificidades da profissão vivida no passado, com objetivo de entender a real dimensão dos seus projetos de vida e de seus desejos no presente. Projetos e desejos que estão diretamente fundidos ao universo da aviação no Brasil e à função simbólica do imaginário.

Como já foi observado em outra pesquisa (Rodrigues 2000), a aviação, apesar de ser um espaço dominado pela técnica, pelos procedimentos frios de um computador, está repleta da fascinação daqueles que observam e, por que não dizer, daqueles que participam de maneira mais direta deste mundo. Busco demonstrar que os relatos atuais sobre o conjunto de habilidades vividas por meio do trabalho na aviação permitem a eles uma reação positivamente relacionada aos valores apreendidos nos anos de VARIG.

Para tanto, o papel da memória na vida das pessoas nos mostra um caminho promissor na direção da compreensão desejada. Assim como salientou Lopes (2011) com relação aos trabalhadores industriais, afirmo que os ex-trabalhadores da VARIG, de símbolo de progresso, mudança e transformação social, passaram a ser objeto de memória. A pesquisa realizada busca, portanto, responder à necessidade de incorporar o estudo da memória e das trajetórias profissionais como chave para a compreensão dos processos de transformação acelerada, que vêm atravessando a sociedade e a cultura brasileiras. 
Considero o fechamento da VARIG como paradigmático na história da aviação civil do país, sobretudo no que concerne aos trabalhadores, à construção de suas identidades, suas formas de sociabilidade, sua orientação em face ao Estado e às empresas, assim como às novas formas de organização do trabalhador na conquista de seus projetos para a vida. "Projetos para a vida" aqui entendidos como padrões culturais, junto com Geertz (1966:42) e Kluckhohn (apud Geertz 1966:42). É também um caso paradigmático no que se refere ao processo de falência dos direitos dos passageiros. Desde o fechamento da VARIG, novas regras surgiram no mercado, por exemplo, a criação de taxas extras, como pagamentos para despachar a primeira bagagem, para ocupar assento com maior espaço e até mesmo para reserva antecipada de assento, sendo ou não especial. Sem falar no aumento do número de escalas, pouca oferta de voos, monopólio de rotas e diminuição da concorrência.

A vertente teórica adotada na pesquisa compartilha do paradigma hermenêutico, sobretudo de autores que consideram a imagem, o nível simbólico, como local de mediação para tomada de atitudes diante dos desafios da vida. Utilizei as bases teóricas de Gilbert Durand (1983, 1997), Edgar Morin (1975), Pierre Bourdieu (1989, 1998), Clifford Geertz (1966, 1978, 1998), entre outros. Ou seja, dialogo com autores que consideram as imagens como totalidades multiformes e vetores de formação da dinâmica cultural. Imagens que permitem a conservação, a produção de ficção, assim como as transformações sociais. Imagens que dizem respeito às tradicionais categorias subjetivas implicadas em uma relação dialógica, responsáveis pela produção de vários níveis da subjetividade do trabalhador. Trata-se de uma dialógica, portanto, de uma lógica ternária. Lógica na qual os pares de opostos se encontram em eterna tensão, fomentados por um terceiro elemento, que jamais resultará em uma síntese. Os valores imagéticos, que obsidiam o universo pesquisado, assim como contextos e ações, concebidos como importantes na análise dos dados, serão encontrados neste artigo por meio de destaques em negrito.

Em termos teóricos, considero a organização humana cada vez mais, segundo as afirmativas de Morin (1975), sob o signo da desordem. O ser humano, como eternamente inacabado, uma quimera, em busca da eterna juventude (Morin 1975:149, 150, 151). O que se procura evitar é o reducionismo epistemológico e, com ele, a ideia de que a desordem é um elemento apenas desestruturante dos projetos de vida.

No sentido de buscar compreender o uso da técnica, permeado por valores culturais, considero que uma profissão designa uma realidade objetiva, relacionada ao sustento próprio e familiar, dotada de ação intencional e pragmática, de obrigações, normas, funções e responsabilidades. Ao mesmo tempo, pondero a relação pessoal com o trabalho como subjetiva e íntima, desenvolvendo-se por meio de um conjunto de representações e de simbologias, que podem transformar os projetos culturais dos trabalhadores, os sobrecarregando de valores negativos ou positivos. As imagens criadas em torno do trabalho aéreo formam-se tanto em sua vertente interior - imagens de prazer, de sofrimento, de patologias - quanto em sua vertente exterior, em sua superfície visível, estando seus uniformes e objetos técnicos revestidos não somente de praticidades, como de símbolos, estendidos até mesmo às formas gestuais. 
Sahlins (1979), em "Cultura e razão prática”, já chamou atenção para o fato de que a realização prática pelo trabalho está intrinsecamente relacionada ao que é instituído como desejante em cada cultura. Ele alerta para o fato de que a qualidade de uma determinada cultura não se prende apenas ao ato de conformar-se a pressões materiais, mas a fazê-lo de acordo com um esquema simbólico definido, que nunca é o único possível (Sahlins 1979:8). Cultura e razão prática definem valores locais e se expressam na forma de identidade do grupo social. A experiência vivida no trabalho oscila, portanto, entre um trabalho necessário e real, acessível ao olhar de todos, e outra dimensão feita de possíveis, de devaneios, de fantasias, de irrealidades que o podem esvaziar, expandir, duplicar, mascarar ou mesmo fazê-lo indesejado paulatinamente.

No caso estudado, a experiência vivida ao trabalhar na aviação e as insistentes e saudosas referências de satisfação, orgulho, paixão e amor devem-se, muito provavelmente, à importância que as próprias características desse ramo de atuação assumem, por meio das marcas e dos sentidos da sua trajetória. Os valores da profissão de aeronautas e de aeroviários (Rodrigues 2000) estão repletos de devaneios, que começam a ser tecidos no passado, quando a humanidade se sentiu atraída pela magia de voar, e quando surgem os primeiros sonhos acordados de elevação. Remete a um tempo que reanima a memória dos mitos de ascensão e do voo, ao tempo dos xamãs e das bruxas, da magia daqueles que já voavam bem antes dos pilotos atuais. A aviação fornece uma forma alongada à modernidade, pois se projeta sobre uma tradição, iniciada, para a memória da civilização ocidental, na Antiguidade Clássica, saída do mito de Dédalo e Ícaro, até alcançar os dias de hoje. Trata-se de uma memória expandida.

A memória não se pretende como verdadeira, mas dilemática, carregada de contradições, paradoxos, que, apesar da possibilidade de serem conciliados temporariamente, estão desvinculados da noção de tempo lógico, métrico, matemático. Durand (1997) alerta que a memória é o poder reflexógeno geral da vida e, como tal, tem a capacidade de reação, de regresso, enfim, de uma organização que nega a irreversibilidade do tempo. A memória como imagem, diz o autor, "é essa magia vicariante pela qual um fragmento existencial pode resumir e simbolizar a totalidade do tempo reencontrado" (Durand 1997:403).

Para Durand, é possível construir uma escala de realização do mito. O autor pega emprestado o conceito de distância do real, que vem de Abraham Moles. Ele toma como exemplo o mito de Ícaro que, pertencendo aos grandes sonhos, já é mais ou menos realizado pela ciência, pela técnica:

Nos nossos dias, quando se vê na
televisão os cosmonautas que pousam
o pé na lua, já não é um mito [...] tendes
aí uma distância do real que é muito
pequena, de onde, paralelamente, a
mitologização dos cosmonautas, são
personagens que se divinizaram -
ou dos grandes aviadores de minha
juventude, como Lindbergh, que foram
personagens absolutamente míticos
mas realizados (Durand 1983:57).

Voar, ter liberdade e enganar o tempo, eternizando-se, características do universo aéreo, permitem que a constelação de imagens associadas a esse universo multiplique-se. Prometeu e Ícaro 
estão juntos no que se refere ao tema da liberdade, o qual é flutuante, integra-se tanto ao mito de Ícaro como ao de Prometeu. O mesmo acontece com o tema da imortalidade. Apesar de Prometeu ocupar o papel de ladrão de imortalidade, Ícaro também eterniza o momento do voo. Ou melhor, quando Ícaro atinge seu objetivo (a realização do voo que deseja), por meio de seu esforço e trabalho, esvazia o sentido moral e mortal da queda. A liberdade, diz Durand (1997:400), "é um repouso, luxo supremo que engana o destino. $\mathrm{O}$ valor situa-se na explosão do devir”.

É difícil descrever, nos limites de um artigo, o cenário simbólico relatado. Cenário em que o grupo profissional estudado esteve inserido antes do leilão e posteriormente ao fechamento da empresa. Os entrevistados desta pesquisa foram artífices de uma empresa que alcançou setenta e nove anos de vida, possuiu mais de 33 empresas no Brasil, entre elas, rede de hotéis, banco, locadora de automóveis etc. Chegou a ter cento e vinte e sete aviões, aproximadamente vinte mil funcionários e oferecer viagens com destinos para trinta e seis países. A VARIG foi uma empresa aérea que, por um lado, permitia ao trabalhador o convívio dentro de uma lógica funcional, pragmática e, acima de tudo, econômica, por outro, não se dissociava de um sentido oculto ou mesmo inacessível, muito próximo ao conceito de símbolo na perspectiva durandiana. Nesse sentido, foi possuidora de um significado especial, relacionado à ostentação, ao luxo e ao crescimento do próprio Estado brasileiro.

Considera-se aqui o caráter pluridimensional do símbolo, na medida em que ele permite "ligar, além das contradições naturais, os elementos inconciliáveis, as barreiras sociais e as segregações dos períodos da história" (Durand 1997:38). A VARIG foi, portanto, um símbolo nacional, do progresso, da modernidade, sem perder, contudo, seu estatuto de empresa tradicional e internacional. A memória da VARIG também fornece uma forma alongada à modernidade. Surge na memória dos variguianos como a primeira e mais importante empresa aérea brasileira de todos os tempos.

O leilão e a decretação de sua falência ocorreram a partir de uma nova legislatura. O que veiculou a imprensa foi que a empresa veio a ser uma das primeiras a se "beneficiar", em 2005, da Lei de Falência - como é chamada a Lei Federal n. 11.101/2005 (Brasil 2005). Tese de Romeiro (2014), defendida no Programa de Pós-Graduação em Sociologia e Direito, na Universidade Federal Fluminense (UFF), assevera que:

o que se verificou foi que a recuperação
judicial permitiu a alienação da parte
produtiva solvável e das subsidiárias
lucrativas, mas a VARIG, em si, não
foi recuperada, ficando com a dívida,
além dos trabalhadores se sujeitarem
aos riscos do negócio, quando o
acordo judicial os fez suportar todo
o ônus da atividade empresarial; às
demoras processuais, quando exigiu
que aguardassem anos sem receber,
e à imperatividade do juízo, que
mesmo sem a observância da norma
do artigo 612 da CLT, declarou o Plano
de Recuperação Judicial cumprido,
restringindo frontalmente os direitos
dos trabalhadores, via Acordo Coletivo
de Trabalho, alterando o seu statuspara
investidor/debenturista, enquanto que
nem ao mínimo tiveram direito. Nem
mesmo as instituições que deveriam
proteger os abusos, ou seja, o MPE e o
administrador judicial, e que deveriam


zelar pelo princípio da função social da empresa, não o fizeram, violando, inclusive, a norma de garantia mínima salarial, prevista no artigo 54 da LREF e aplicando interpretações contrárias à lei, para salvaguardar o interesse de determinados grupos (Romeiro 2014:7).

Na opinião, no entanto, do vice-presidente da Associação de Pilotos da VARIG (APVAR), "Vendeu-se a empresa para recuperá-la, o que já é uma incoerência jurídica. A situação só piorou e não pagaram absolutamente nada aos trabalhadores. Foi um golpe clássico e descarado" (Melo \& Araujo 2018). Segundo relatos partilhados, além de não ter se recuperado financeiramente, a companhia acumulou uma dívida ainda maior, a qual aumentou de $\mathrm{R} \$ 7$ bilhões para $\mathrm{R} \$ 18$ bilhões, em 2018, dando um salto de $157 \%$.

Não há números precisos, mas estima-se que pelo menos cerca de nove mil e quinhentos funcionários ainda existiam quando da venda da empresa, segundo dados fornecidos pelo Sindicato dos Aeroviários. Conta-se mais de mil funcionários mortos após o seu fechamento, entre eles a primeira morte registrada, em julho de 2006, foi a do piloto Rodrigo da Matta, filho do antropólogo Roberto da Matta, em sua residência, por ataque fulminante do coração. No mesmo mês, a VARIG anunciava a demissão coletiva de 5.500 funcionários (Nascimento 2006). Conforme relatos, o piloto tinha acabado de passar nos exames médicos exigidos para a renovação de sua licença, mas o estresse que vinha acumulando, somado ao choque do anúncio do leilão e das demissões, foi demais para ele. Rodrigo morreu aos 44 anos. A última morte a que tive acesso em campo foi em razão de um suicídio. Segundo notícia veiculada na mídia, o ex-comissário Guilherme Ribeiro Gottel suicidou-se como provável consequência da desestruturação de seu projeto de vida, no dia 25 de julho de 2018, na casa de sua mãe, na Ilha do Governador, no Rio de Janeiro ${ }^{1}$, onde passou a morar após separação da esposa.

Como muitos relatam, a VARIG era uma empresa onde as pessoas nasciam, cresciam, trabalhavam e morriam, apoiadas por um grupo fiel de funcionários e de administradores. Conforme entrevistas e sites, até o ano de 2018, havia ainda mobilização dos "sobreviventes", todas as quartasfeiras úteis, em frente ao Tribunal de Justiça do Rio de Janeiro (TJRJ), solicitando indenizações e direitos retirados. No cotidiano da cidade, no entanto, não se ouve mais falar daquela que durante décadas foi a maior companhia aérea da América Latina.

Do ponto de vista antropológico, levo em consideração que a construção dos valores e dos significados para o grupo se faz por meios simbólicos e culturais; consequentemente, a ordenação e a organização da experiência e da ação humanas dependem de uma construção irredutível apenas relacionada ao mero rendimento em dinheiro e à racionalização do comportamento.

É preciso abrir outro parêntese importante nesta introdução. Diferentemente de Clifford Geertz (1978), no capítulo "Um jogo absorvente: notas sobre a briga de galos balinesa", quando descreve como se sentia em sua pesquisa de veiculada em Melo \& Araujo (2018). 
campo em Bali, eu fazia parte da rinha. Portanto, posso dizer que, de certa forma, foi nas figuras de profissionais da aviação encontradas nos tios, primos e pai (lembranças infantis) e, posteriormente, na minha própria experiência (o contato e a vivência com o grupo pesquisado) que a problemática foi se delimitando. Trago para essa investigação igualmente os anos em que trabalhei em empresas aéreas. Somente por meio do afastamento necessário para a pesquisa, no entanto, compreendi os fatores, ou poderíamos dizer, as pulsões que levavam as pessoas desse universo a acreditarem que é quase impossível sair deste emprego.

É, portanto, com a mesma fidelidade, outrora inconsciente, que escrevo cada linha deste artigo. Responsabilidade, amor, respeito, confiança, como muito bem descreveu Eugène Enriquez (1997), devem fazer parte de todo trabalho que se deseja publicar: "Ora, um livro só o é de verdade se foi desejado, escolhido, sonhado e se foi escrito com amor. As palavras fazem amor, dizia André Breton” (Enriquez 1997:8). Espero poder demonstrá-lo.

Por fim, busquei pautar a descrição e a análise dos fatos para além das razões de ordem histórica, na medida em que, depois do leilão da empresa, os movimentos a favor dela e dos direitos dos trabalhadores passaram rapidamente ao esquecimento geral. A análise das ações práticas verificadas em pesquisa de campo, na direção da luta por manter viva a memória do grupo, faz concordar com a afirmativa de Ricoeur, de que o esquecimento "é o emblema de quão vulnerável é nossa condição histórica" (Ricoeur 2007:300). O esquecimento coletivo da
VARIG, portanto, pode revelar indícios de uma interpretação vulnerável dos acontecimentos e de uma atitude ideológica social diante da "naturalização" das perdas de direitos, inclusive trabalhistas, em curso no Estado.

Veremos, na conclusão deste artigo, que as imagens simbólicas e as suas raízes afetivas, ao tomarem lugar no âmago da condição humana, vão ao fundo do ator social e possuem significação no seu intelecto; por outro lado, as imagens que permeiam esse universo estão carregadas de um determinismo eficaz, sem, contudo, estarem reduzidas ao aspecto meramente funcional. Observaremos, ainda, que a sensação de potência, de liberdade, de eternidade, o prazer de fazer parte de algo importante para a humanidade, o senso da responsabilidade por vidas, o estudo constante e, por fim, o improvável das situações cotidianas, que prescinde de capacidade e rapidez para lidar com o imprevisto, com decisões imediatas, exigia deles uma importante habilidade: a de saber como se relacionar com o novo.

A metodologia partiu de uma abordagem de caráter etnográfico e qualitativo, envolvendo entrevistas com ex-trabalhadores e com membros de sindicatos e órgãos representativos. Os passos metodológicos incluíram a realização de um levantamento documental nos sindicatos e na imprensa sobre o desmantelamento do grupo, as consequências na vida profissional, o desemprego, o trabalho informal e a história das suas relações de alteridades. A pesquisa, portanto, se insere nos estudos vinculados à problemática do trabalho e do imaginário, 
buscando avançar na construção de um campo de análises sobre a memória, a dimensão simbólica e as transformações sociais.

O artigo está baseado na análise de entrevistas, assim como na análise de sites, a maioria deles criada pelos próprios exfuncionários com a intenção de registrar queixas e insatisfações, rememorar histórias saudosas e perenizar memórias compartilhadas. As entrevistas, em número de quinze, foram idealizadas como instrumento para que eles pudessem falar livremente de suas trajetórias, após a saída da VARIG. O caminho das narrativas diz respeito aos momentos que vão desde a entrada na empresa, o desfecho traumático e, por fim, o momento atual vivido. Nas falas, buscaram-se as articulações, os paralelos ou as contradições entre as narrativas e as suas posições atuais como profissionais em novas áreas de trabalho ou em novas empresas do ramo aeroviário.

Uma preocupação inicial era de não me deixar enredar pelo fascínio das narrativas longas. As entrevistas sempre ultrapassaram a margem duas horas e, na maioria dos casos, ainda terminavam em algum local aprazível para um lanche. Entre um pastel e outros petiscos, surgiam novas observações sobre o que foi dito. Acréscimos e justificativas pareciam inevitáveis, porém, sem o registro de áudio ou anotações. Neste artigo, irei utilizar duas entrevistas e a análise das justificativas das recusas para não participar da pesquisa. Fiz essa escolha por considerá-las as que mais sintetizam núcleos temáticos recorrentes. Vale ressaltar que utilizo nomes fictícios por opção própria. Nenhum dos entrevistados solicitou anonimato sobre a provável exposição das declarações feitas.

\section{VARIG! VARIG! VARIG!}

Um dos jingles de sucesso da empresa, "VARIG! VARIG! VARIG!" foi encontrado em diversos sites e blogs de ex-variguianos. A expressão surge como reafirmação de uma imagem perene, acompanhada de relatos do tipo, "uma vez variguiano, para sempre variguiano".

Do ponto de vista social, é bastante surpreendente a presença da VARIG na vida cotidiana das cidades em que possuía bases, principalmente aquelas com maior representatividade de funcionários e voos. Numerosos seriam os exemplos da função social que chegou a exercer. A maioria delas é descrita com muito orgulho pelos ex-variguianos e influía de forma direta na identidade construída e em seus projetos de vida no passado. Eram oferecidas desde viagens gratuitas para crianças que precisavam de "tratamento aéreo" (leia-se, ar mais rarefeito), para se curar da coqueluche, nas décadas de 1950 a 1970, até a importação e o transporte de medicamentos inexistentes no Brasil, como no início da disseminação do vírus HIV, no final do século XX. A representatividade e o alcance da sua presença fora dos limites da empresa atingiam a vida de pessoas com as quais nem mesmo seus funcionários poderiam imaginar. Destaco a inusitada presença da VARIG na vida dos catadores e das catadoras de lixo daquele que foi o maior aterro da América Latina, localizado em Jardim Gramacho, um bairro do município de Duque de Caxias, na Baixada Fluminense. 
Em entrevista dada no ano de 2012, uma catadora de lixo destaca que ela e o grupo de catadores percebiam a VARIG como responsável por proporcionar as boas memórias do seu ofício, resgatadas aqui por meio da dissertação de mestrado em Antropologia de Adriana Xerez:

[...] ela nos conta das maravilhas do lixo da VARIG, lembrança essa compartilhada por muitos catadores. Havia os talheres de alumínio, os doces que vinham bem embalados e frescos, além das garrafas de champanhe que chegavam intactas. Quando o lixo da VARIG caía no aterro, era uma verdadeira festa. Glória brinca que ficava admirada com o lixo da companhia de aviação e lembra da decepção que foi sua primeira viagem de avião com as barras de cereal e o suco de caixinha. Sentiuse em um ônibus (Xerez 2013:38, 39).

Xerez (2013) afirma, sobretudo, que o lixo da VARIG era motivo de atração para se trabalhar no aterro. A análise dos relatos realizada por esta autora identificou que a VARIG era vista como fator motivacional para enfrentar o processo de iniciação como catadoras. Conforme registro de Xerez (2013:49), a entrevistada afirma que "foi atraída pelo lixo da VARIG, de que todos falavam".

A queda da empresa, como se pode ver, atingiu diversas dimensões cotidianas e representativas, mesmo fora do seu quadro de funcionários. O acróstico da empresa, visível por anos na extensão da praia do Flamengo, é outro exemplo. Localizado acima do prédio, de propriedade da empresa, ao lado do Santos Dumont, hoje hotel de luxo, era considerado parte integrante de um dos cenários mais valorizados da cidade do Rio de Janeiro. De certa forma, contribuía com a identidade daquela paisagem. A retirada do nome da empresa, assim como do acróstico da VASP, foi motivo de reportagens, que denunciavam um vazio no cenário visual do Parque do Flamengo.

\section{0 CAMINHAR DAS NARRATIVAS: MITOLOGIAS E RAZÃO PRÁTICA}

\author{
Os símbolos, ideias, mitos, criaram \\ um universo onde os nossos espíritos \\ habitam (Edgar Morin).
}

Inicio a análise efetiva dos dados e dos relatos obtidos na pesquisa, afirmando que as narrativas e as imagens encontradas em campo são emblemáticas. As profissões procuradas fora da aviação mantiveramse ligadas, de certa forma, às imagens de liberdade, de transcendência e de imortalidade, dimensões presentes no grupo e que são responsáveis pela união e por muitas das ações desenvolvidas após o fechamento da empresa. Trabalhar na VARIG, nas palavras dos entrevistados, além de um bom salário material, oferecia um bom salário psicológico. Aqueles que procuraram novos ofícios, por não conseguirem espaço em outras companhias, foram trabalhar com o transporte terrestre. Transportando coisas e pessoas, viraram motoristas de taxi, de camionetes, muitos estão trabalhando via um aplicativo de corridas de passageiros. Existem aqueles que foram para a área de turismo, abriram pequenos comércios relacionados ao lazer (como quiosques ou trailers de praia), são 
vendedores ambulantes, outros ainda investiram o tempo estudando para passar em concursos. Sem falar de muitos variguianos que seguiram carreira internacional, após o fim da companhia ${ }^{2}$. A maioria deles é composta por aeronautas, pilotos, comissários de bordo e os que já moravam fora do Brasil. Há, contudo, registro de um ex-comissário que virou morador de rua. O grupo de aposentados foi bastante afetado. $\mathrm{O}$ fundo de pensão complementar de aposentadoria, mantido majoritariamente pela VARIG, o AERUS, faliu. Mesmo com a garantia do rendimento proveniente do Instituto Nacional do Seguro Social (INSS), precisaram complementar renda.

Muitos dos relatos são comoventes, com uma expressiva quantidade deles exposta nos sites pesquisados, que objetivam manter viva a memória variguiana e, por consequência, a própria imagem. Com efeito, afirmam: "estamos aposentados, não mortos!". Sobretudo quando motivados pela busca dos seus direitos trabalhistas. Ao mesmo tempo, o teor das entrevistas e das frases disponíveis no espaço cibernético e jornalístico revela que, ao sair da VARIG, algo além do sustento foi retirado deles: "Tiraram de mim não só um emprego; tiraram uma paixão, meu orgulho", declaração feita por uma ex-comissária, com sessenta anos. "Sonho quase todos os dias que estou dentro de um avião, servindo as pessoas. Era a coisa que eu mais amava. Quando acordo, sento na cabeceira da cama e choro. Sei que, pela idade, é algo que não vou mais voltar a fazer", declaração de outro ex-comissário da VARIG, de 53 anos. Para alguns, mesmo morando de favor em casa de amigos, a esperança se mantém: "A vida é um ciclo. Agora, estamos girando na parte de baixo da roda, mas creio que ela vai girar de novo e vamos parar na parte de cima"3.

Sendo assim, diante desse cenário complexo de funções diferenciadas e pessoas nas mais diversas condições de reação econômica, busquei reunir, por meio dos sentidos e significados dados ao trabalho aeroviário, uma chave para interpretação dos momentos vividos. A ideia é demonstrar que forças movem ainda os ex-funcionários da empresa, independente da atual posição que possuem. Vejamos, no Apêndice 1, relato que condensa as trajetórias profissionais de um exvariguiano, após a falência.

O que eu quero chamar atenção no relato constante do Apêndice 1 é o sentido cíclico dado à vida. Na verdade, para um tempo cíclico, que é bom com o interlocutor, não o levando à morte; um tempo similar a um tempo litúrgico, de uma temporalidade sagrada e possuidora de um presente eterno, vivido por meio do trabalho na aviação. $\mathrm{O}$ fato de o entrevistado não querer se aposentar, o fato de viver o presente, de sentir-se sereno e, ao mesmo tempo, impulsivo, segue na temática do eterno retorno, de uma eternidade que, mesmo após ter o fígado devorado, como Dédalo, após o fechamento da VARIG, ele volta a nascer no dia seguinte. Esses significados associados ao seu trabalho, além do sentimento de plenitude e de totalidade que a experiência de participar dele oferece, se relacionam com a missão de continuar a

2 Estima-se que seiscentos pilotos estão ainda voando fora do país, assim como não foram absorvidos sequer $8 \%$ dos funcionários da VARIG no mercado nacional. A informação também é veiculada em Melo \& Araujo (2018).

3 Relatos disponíveis em Melo \& Araujo (2018). 
existir como projeto de vida. E a missão da vida para Durand (1997:400) é “'retardar' a queda de energia; por esta dilatação da morte, é anunciadora da liberdade". Como se aposentar, então?

Na obra "Ensaio sobre a dádiva", Mauss (1974) chama a atenção para a existência do jogo entre liberdade aparente e constrição verdadeira, que, para ele, existe em toda sociedade humana. O que faz com que os funcionários, no caso específico da aviação, não se sintam apenas como sujeitos "aprisionados" por um contrato de trabalho ao exercerem suas funções? Por que se sentem satisfeitos, bem na sua pele, como diriam os franceses, no local e na função que habitam? Quais são os "presentes voluntários" trocados? A análise dos relatos permite contemplar o fato de que, apesar de toda a rigidez, o controle, a precisão e a disciplina exigidas no trabalho, as obrigações realizadas são fartamente recompensadas pelo sentido de liberdade e de segurança. A segurança não é vista apenas pelo progresso das técnicas, mas pela possibilidade de produzir arte no trabalho ou pelo menos de senti-la. De forma linear, como assevera Durand, o sapateiro mantém sua arte, na medida em que "o verdadeiro processo de hominização não consiste no fato ou no processo da vida, nem no progresso das técnicas. Situa-se nos valores 'estéticos', isto é, no nível da invenção dos ritmos, dos símbolos, da arte" (Durand
1995:140). O trabalho aeroviário, nesse aspecto, tem a ver com o ritmo das suas próprias vidas, com uma cotidiana explosão do devir (Durand 1997:400). A maximização da responsabilidade de todos não é sentida como coerção, mas, antes disso, é um projeto de vida coletivo. Com efeito, posso dizer que vemos interligadas as simbologias da arte e das invenções dos ritmos com o trabalho aeroviário, proporcionadas pelos valores e atrativos estéticos que as mobilizam.

André Comte-Sponville (1984:219), em sua obra "Le mythe d'Icare: traité du désespoir et de la béatitude", faz uma analogia entre o artista e o personagem de Ícaro. O artista/poeta é como um militante que assalta o céu, mesmo que o céu não exista. É ele que constrói sua rota para o céu e, nesse sentido, Ícaro é a sua casa, é o chefe do seu trabalho. Ícaro funciona como metáfora da eternidade, pois a sua queda não muda nada neste cenário. Afinal, Ícaro é a história de uma ascensão furiosa, vertical. Para Durand (1997:134, 135), a intenção do voo é sempre a ascensão, meio simbólico de transcendência. O importante é a linha que o voo de Ícaro conseguiu fazer ou, no caso do poeta, a linha que o voo do poema fez, e é ela quem irá conservar-se na imagem infinita dos seres vivos: "O poeta tira o melhor de seu próprio desastre", afirma Comte-Sponville (1984:219). Da mesma forma, as atitudes prometeicas ${ }^{4}$ de aceitar desafios, enfrentá-los e acabar triunfante estão permeadas por uma racionalidade instrumental, por uma racionalidade de meios, por uma

4 Prometeu foi um titã da mitologia grega que roubou de Zeus o fogo do céu para trazê-lo à terra e oferecê-lo aos homens. Zeus o condenou a ser acorrentado num rochedo, onde todos os dias um abutre lhe devorava o fígado, que voltava a nascer. Foi o Centauro Quirão que pôs fim ao seu sofrimento, entregando-lhe sua imortalidade, e Prometeu pôde, assim, ascender à esfera dos Deuses. 
desobediência tecnocrática hábil ${ }^{5}$, que lhe garante a vitória.

É o estar agarrado ao trabalho que lhe permite o tempo das viagens e do conhecimento, a experiência, a liberdade, os valores da vontade, e todos eles reunidos enchem de sentidos a profissão, os quais relacionamse com a função fantástica do imaginário pelo poder de bloquear o fatal determinismo do destino. Para Durand (1997:311), a função fantástica do imaginário tem o sentido de instituir-se contra o destino mortal. A intensa e a imediata projeção de imagens voltadas para os sentidos da liberdade e do conhecimento relatados sugerem a busca por atividades que permitam aos ex-variguianos se manterem fora do tempo fatal. No caso do entrevistado, aos sessenta anos sente-se, na verdade, com quinze e está em busca de iniciar um novo curso universitário. Poderia ser em música, pois frequenta todos os sábados o curso de extensão da Universidade Federal do Rio de Janeiro (UFRJ) para músicos, porém se inscreveu para Ciências Aeronáuticas, mesmo sendo à distância. O único curso de graduação nessa área, no Brasil.

Outro aspecto que parece ser derivado de sua identidade profissional variguiana está relacionado à falta de ambição. Com efeito, o fato de ser um profissional padrão VARIG, ou seja, fazer o seu trabalho com responsabilidade e competência apesar de não ter dedicado esforços na VARIG para galgar o poder e assumir uma supervisão ou gerência -, não se distancia de uma política e de uma narrativa há muito valorizadas dentro da própria empresa. Valores que parecem se manter no tempo, para muitos que já participaram dela. Sacrifícios, visão social, devotamento, esforço, dedicação e disciplina formavam uma base identitária profissional de grande importância no seio da organização aeroviária. Revelam ligações com o passado e dão lugar social àqueles dispostos a reproduzi-los em sua prática cotidiana, mesmo sem ocupar cargo de chefia.

Xausa (1993), no início da década de 1990, demonstrou, em entrevista realizada com o diretor de administração da empresa, admitido na VARIG em 1956, a valorização de determinadas características associadas à identidade variguiana. Nas palavras do diretor:

Esta disciplina eu colocaria em primeiro
lugar e, em segundo plano, esta "falta de
ambição", porque a VARIG foi, ao passar
destes 35 anos, tendo uma trajetória sem
ambições, sem guerras internas [...].
Mas os homens da VARIG [...] sempre
foram desprendidos no sentido de não
ter ambições pelo poder, quer dizer, o
poder é para todos nós, e eu estou há
20 anos como diretor, o poder sempre
foi uma forma de você querer mais
coisas para fazer. É diferente do poder
que visa status, que visa prerrogativas
e privilégios. Não. Poder sempre foi
alguma coisa que a gente buscava no
sentido de atender bem os destinos da
organização; o poder sempre foi uma
forma de você querer dar mais e não de
querer tirar mais [...], fundamentalmente
estas duas coisas que deram sustentação:
disciplina interna e "desambição" dos
homens, ao longo de sua trajetória
histórica, e é muito importante porque

5 A desobediência hábil é um dos mitemas que compõe o Mito de Prometeu, segundo Gilbert Durand. Nesse aspecto, introduzi a palavra "tecnocrático" apenas para aproximá-la ainda mais da valorização técnica a que a aviação remete. Gilbert Durand reconstitui um tipo ideal do mito de Prometeu, com base em mitemas originários, fixos em qualidade e em quantidade, que se alicerçam em atos, situações e cenários, quais sejam a natureza titanesca, a desobediência hábil, o castigo, o pai dos homens, a liberdade e a imortalidade. 
isto faz com que o sentido de equipe, de família, seja preservado. São dois fatores culturais (Xausa 1993:120, 121).

Tomo como exemplo paradigmático os trechos dessa entrevista porque, além de eles se alongarem no tempo (surgindo em relatos de funcionários que entraram na empresa, em 1956), considero aqui a importância da orientação da direção administrativa da empresa para a seleção e a procura de pessoas que congregavam esses perfis. Ou seja, não ser ambicioso, no discurso explícito dos representantes da empresa, fazia parte do funcionário padrão variguiano e que, portanto, não feria a estima pessoal, ao contrário, garantia ainda mais a sua importância e seu espaço dentro dela e, consequentemente, deveria garantir a manutenção do seu emprego. Como no potlatch, para galgar prestígio na VARIG era preciso mostrarse generoso. Certas características dos funcionários não somente eram estimuladas, desde a entrada (1958) do futuro administrador entrevistado por Xausa (1993), como já faziam parte das qualidades esperadas para o futuro empregado nos processos seletivos mais recentes.

O projeto coletivo associado a esses sentidos da vida mostra-se ainda mais importante quando a necessidade prática de manter o sustento próprio aparece como algo de pouca importância. A "sorte" de ter o dinheiro do Fundo de Garantia por Tempo de Serviço (FGTS) nas mãos, para poder se dedicar a outro ofício, era algo lamentável e lamentada por não ter mais aquele lugar variguiano para habitar, lugar do qual ele nunca quis sair (muito menos acreditava que ia sair ou mesmo que a empresa poderia acabar). De certa forma, todas essas emoções permaneceram presentes nas decisões de um novo, ou melhor, de um renovado projeto de vida, fincado em valores que apreendeu nos seus dezoito anos de trabalho.

Por fim, do ponto de vista de uma importante representação simbólica, vemos surgir, no seu relato, um personagem mítico explícito, qual seja Deus. A coerência é imagética e repleta de pulsão pela vida. Poderíamos dizer, em termos durandianos, que, nesse caso: "as imagens figurativas de Deus podem passar justificadamente por modelo de todo antidestino, pelo que transcende as fatalidades lineares de um tempo newtoniano e das causalidades entrópicas" (Durand 1995:142). Dessa forma, mais uma vez, está presente a negação de um tempo dramático para eles, a negação da própria morte profissional, na medida em que o Eterno abole os valores cotidianos (Durand 1995:143). Mais uma vez, destaco, no relato do Apêndice 1, a ênfase na transitividade e na circularidade dinâmicas, criadoras da necessidade de opções por vezes não duradouras, mas constante e conscientemente renovadas. A figura de Deus, redundante na maioria das entrevistas, tem como função a transcendência diante das situações efêmeras e da frágil e soberba segurança que a história lhes oferece (Durand 1995:170).

Neste particular, as qualidades dos heróis solares valorizadas no meio aeroviário encontram-se nas características dos personagens míticos que sobrevivem na memória dos ex-funcionários da aviação. Na sua maioria, são os fundadores, os primeiros administradores das empresas aéreas ou o próprio Santos Dumont. Eles são os benfeitores da aviação, aqueles que não só tornaram possível ao homem voar, mas que faziam questão de dividir com todos as benesses alcançadas por seu investimento. Essas formas míticas estão vivas e são expressas por meio de lamentos na memória do grupo. Os relatos são seguidos por queixas de um tempo que não existe mais. Atingidos primeiro pela precarização e 
depois pelo desemprego, administradores como Ruben Berta, o comandante Rolim, são lembrados para mostrar que os propósitos deles foram esquecidos. Os relatos sugerem o caráter quase filantrópico dos fundadores e dos antigos presidentes das empresas aéreas.

É possível verificar, por meio dos reencontros organizados (Figura 1) e do compartilhamento de espaços, mesmo aqueles com objetivos pragmáticos para reivindicação de seus direitos, o quanto a memória tem papel importante. Percebemos aquilo que Durand chamou de reintegração de um tempo perdido por meio da memória. Assim, a vida profissional recomeça não só a partir de fragmentos vividos, mas dos sentimentos de potência e da possibilidade de enfrentar novos desafios em locais diferentes. Reunidos em novos espaços compartilhados, buscam no elã coletivo e no rememorar de momentos felizes forças para assegurar, nas flutuações do destino, a sobrevivência e a perenidade do grupo (Durand 1997).

Manter-se como um profissional padrão em outros ofícios ou reconhecer um passado de glórias pessoais e grupais permite a recordação de acontecimentos do passado no presente, dando lugar, portanto, à criação e ao redobramento dos instantes. Segundo Durand, a memória se integraliza com a função fantástica do imaginário, pois:

Longe de estar às ordens do tempo, a memória permite um redobramento dos instantes e um desdobramento do presente; ela dá uma espessura inusitada ao monótono e fatal escoamento do devir, e assegura nas flutuações do destino a sobrevivência e a perenidade da substância [...]. A memória pertence de fato ao domínio do fantástico, dado que organiza esteticamente a recordação (Durand 1997:402).

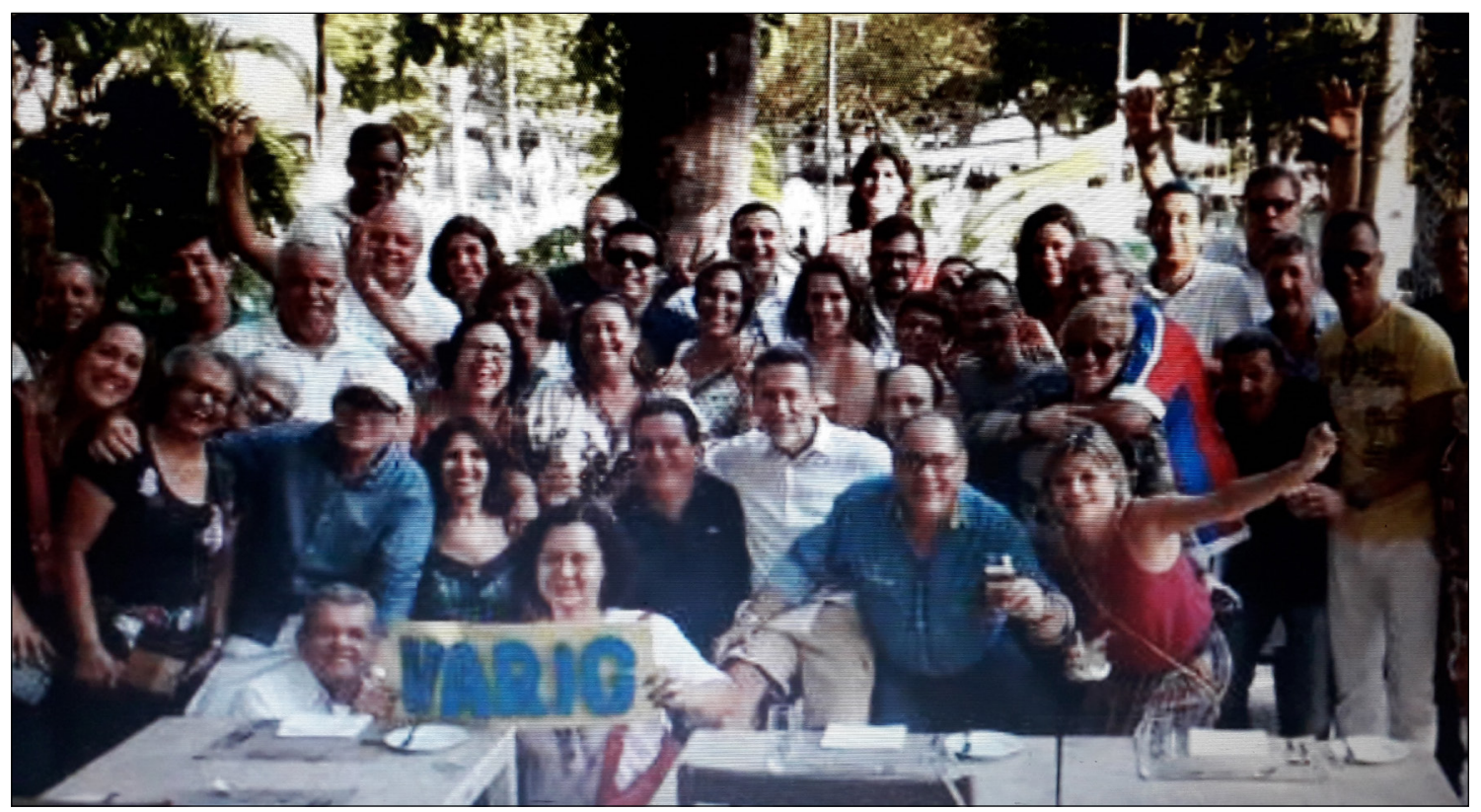

Figura 1 - Encontro de ex-variguianos em hotel de luxo que foi propriedade da VARIG (2017). Neste encontro, foram simbolicamente celebrados os 90 anos da VARIG. Foto: acervo de Miriam Alves. 
O espaço representativo que a memória ocupa para o grupo, seja por meio da manutenção de objetos, uniformes, seja por meio das histórias e de seus lugares de identificação, ao se tornar dominante em relação a um todo, concede a esse grupo a possibilidade de reversibilidade no tempo, de "deter o voo do tempo" (Bachelard 1976:24). Para o autor, o espaço é o local onde se mantém o tempo comprimido.

Em uma análise que busca ultrapassar a noção de espaço apenas como um meio material, determinado, Bachelard (1976:25) chama a atenção para o fato de que o espaço e a memória se estabelecem a partir da vivência íntima e interior, chegando a afirmar que "as lembranças são imóveis e tanto mais sólidas quanto mais espacializadas”. Daí, apesar de considerar as representações do tempo e do espaço indissociáveis da memória, reserva ao espaço uma posição de maior destaque:

\begin{abstract}
Aqui o espaço é tudo, porque o tempo não mais anima a memória. A memória - coisa estranha! - não registra a duração concreta, a duração no sentido bergsoniano. Não se podem reviver as durações abolidas. Só se pode pensá-las na linha de um tempo abstrato privado de toda densidade. É pelo espaço, é no espaço que encontramos os belos fósseis de uma duração concretizados em longos estágios [...]. Mais urgente que a determinação das datas é, para o conhecimento da intimidade, a localização nos espaços de nossa intimidade (Bachelard 1976:25).
\end{abstract}

O Museu VARIG, provavelmente, é um espaço íntimo para os variguianos. A possível reabertura desse museu, fechado entre 2005 e 2006, em Porto Alegre, motiva muitos depoimentos no desejo de manter a VARIG viva para as futuras gerações. A contribuição para um possível filme sobre a história da pioneira, como eles gostam de nomear, não somente faz parte das dimensões das identidades dos sujeitos no presente, mantendo memórias vivas, como se revela importante motivador de luta para os projetos de vida. O lugar da memória, portanto, surge como antídoto contra a maré avassaladora de um destino mortal, fornece em superabundância imagens ativas de fé, em novas possibilidades, novas decolagens. Em outros espaços, a memória faz a sutura dos tempos vividos com a manutenção de suas vidas atuais, gerando esquemas de percepção e de ação no mundo social, mesmo estando fora da VARIG.

Vejo surgir na vivência atual do grupo a relação entre memória, identidade e o tema da imortalidade. A experiência simbólica, possibilitada pela memória, surge de modo terapêutico, como mecanismo de autodefesa de um grupo que teve seus projetos de vida ameaçados com o fechamento da empresa. Em seus relatos saudosos, percebo a idealização de um tempo fantástico e sem problemas. Posso dizer que, quando se trata da imagem da própria pessoa ou, no caso, da própria empresa e das relações que se estabeleceram a partir da vivência no trabalho, a atitude adotada pelo grupo é similar àquela adotada na cultura Ocidental, ou seja, a atitude é aquela do Narciso.

Tenho condição, agora, para concluir e para responder à pergunta feita sobre qual é o papel da 
memória e das disputas de sentido no caso estudado: a reprodução de imagens positivas tem como objetivo, por um lado, negar a morte, imortalizando-se, por outro lado, produzir uma imagem de si mesmo, a mais bela possível (narcísica), para convencer a si próprio de sua beleza e importância, e, assim, ganhar autoafirmação. Trata-se aí da representação encomendada, elaborada, pelos próprios donos da imagem. As representações, as imagens de si e da empresa relatadas não fogem a essa tendência e estão guardadas em suas memórias como fatores importantes para os projetos para vida. Não importa o quão próximas do "real" elas estejam, é significativa a potência fundamentalmente simbólica que delas emanam e as categorias motivantes que possuem nos comportamentos elementares do psiquismo humano. Nesse caso, a potência de ligar as contradições naturais e seus elementos inconciliáveis (Durand 1997:38).

Por outro lado, as repetidas falas sobre a queda dessas figuras emblemáticas e o consequente esquecimento da função social das empresas aéreas como um todo direcionam a análise para a situação de abandono e de mudanças nos cenários do trabalho em si.

\section{MEMÓRIA E ESQUECIMENTO: COMPLEMENTARES, CONCORRENTES E ANTAGÔNICOS}

Nesse ponto da análise, a intenção foi trazer o relato específico referente a uma recusa em participar da pesquisa. A importância do relato consistia no fato de esta entrevista explicitar dados que demonstravam a proximidade e a relação anteriormente construída entre a pesquisadora e o pesquisado no passado. No entanto, não foi possível a autorização para uso público deste relato, que representou, para esta pesquisa, um exemplo de uma entrevista "entre aspas" ou mesmo um exemplo de fracasso etnográfico. Insisto, no entanto, em manter algumas reflexões relacionadas à negativa de participação do entrevistado nesta publicação. Primeiro, porque acredito que o silêncio, os não ditos podem ser reveladores e lugares de aprendizado. Em segundo lugar, por ter obtido em pesquisa de campo três outras recusas justificadas pela mesma motivação: essas pessoas informaram que não suportariam relembrar o passado. Apesar da minha insistência em dizer que o interesse da entrevista era saber das trajetórias e dos momentos vividos pós-VARIG.

Como interpretar estas recusas? Eles estariam fartos do assunto VARIG? Não querem mais se identificar com esse grupo? Seria a proximidade da eleição presidencial, radicalmente polarizada entre Haddad e Bolsonaro? Talvez acreditassem que meu candidato não seria o mesmo que o deles? Para a maioria dos funcionários e de suas famílias, a falência da VARIG é responsabilidade de uma trama realizada entre os políticos do Partido dos Trabalhadores, com a anuência de Lula, e, posteriormente, o abandono vivido no governo Dilma. Isto foi verificado em análise de páginas de Facebook e de blogs de ex-variguianos.

$\mathrm{Ou}$, simplesmente, deveria acreditar na fala dos entrevistados e aceitar que, depois de tantas tensões, pressões e perdas, com os dramas pessoais vividos, se recusavam a fazer aquele voo da memória que, no fundo, só os faria sofrer? Por fim, o que fez com que a trajetória de vida após a saída do trabalho na VARIG tenha se tornado algo indesejado de ser narrado? Para onde foi a explosão de devir e os novos valores? 
A partir de minha relação anterior com o "não entrevistado", inspirada em Pollak (1989) e Ricoeur (2007), e por conhecer parte de sua trajetória, busquei encontrar o significado do atual silêncio. Dessa forma, objetivo oferecer um quadro mais completo, sem deixar de fora uma tentativa de expor o porquê de certos ex-funcionários se recusarem a falar de suas trajetórias apelando para os traumas vividos e que as pessoas não gostariam de relembrar, mesmo com a insistência da pesquisadora, ao dizer que não era necessário falar da VARIG e, sim do momento presente.

Peço, portanto, uma dose de vossa indulgência para trazer para esta análise outro conceito, o qual, acredito, irá elucidar melhor o que talvez pudéssemos chamar de fracasso etnográfico. Proponho, para tanto, o conceito de anomia, que pode muito bem nos aproximar da análise do que aconteceu com a trajetória desses trabalhadores.

A mutação irreversível da companhia sugere uma complexidade que nem os conhecimentos de seus funcionários, nem as mitologias incorporadas, muito menos os analistas de plantão estavam preparados para entender ou explicar.

Com efeito, os ex-trabalhadores da extinta VARIG, desde então, vivem permanentemente fortes perturbações. Posso afirmar que eles viveram, e muitos ainda vivem, em anomia. $\mathrm{O}$ conceito de anomia, utilizado por Émile Durkheim (1999, 2000) e Jean Duvignaud (1973), mostra como as sociedades vêm se transformando e provocando diversas reações imprevistas para os trabalhadores e os indivíduos de maneira geral.

A anomia é um conceito de extrema importância para Jean Duvignaud, pois as mutações são condicionantes da vida social. A problemática relacionada a este conceito está irredutivelmente ligada àquele da ruptura social. Por vezes, não somos capazes de perceber o momento em que ela acontece, apenas quando nos defrontamos com suas consequências (Duvignaud 1973:45).

No entanto, a importância principal para se entender a mudança não está na sociedade, mas na individualidade, pois é ela que não só experimenta a mutação, como em grande medida é responsável por esta mudança. $\mathrm{O}$ autor não busca, portanto, por leis ou por uma teoria positiva e controladora. Ele lembra que devemos estudar menos a permanência das estruturas fixas e nos preocupar mais com a mudança, sem encobrir os fatos no vazio da coletividade, mas entender por qual razão, a partir do coletivo, existe o individual (Duvignaud 1973:63).

$\mathrm{Na}$ busca por não encobrir os fatos no vazio do coletivo, acho importante que haja um esforço interpretativo no sentido de compreender as negativas para as entrevistas. $\mathrm{O}$ desfecho da falência mostrou ao grupo como determinadas formas de organizar ofícios e empresas, considerados até então seguros, vêm se transformando e provocando inúmeras reações inesperadas. Os comportamentos inéditos aparecem e tornam-se necessários para a sobrevivência, as normas são contestadas e o desvio se enriquece de novas forças. Se, para alguns, é possível perceber que o sagrado, o imaginário, o sonho, a contestação se insinuam aqui e ali, como forma de encarar a nova situação, suas novas realidades; para outros, o sofrimento, a dor, a saudade, a falta de poder econômico e político entravam as ações e conduzem o grupo a repensar o lugar e o papel das suas escolhas numa sociedade na qual se vive permanentemente fortes perturbações. Suas ações e reformulações da própria vida deixam claro que a vida imaginária desse grupo mudou de 
sentido. Não vale mais a pena falar do passado. A vida passada é negada de uma forma profunda. Afinal, o que permanece?

Na solidão social em que se encontraram, percebem que as formas aparentemente mais estáveis e mais sólidas de sociabilidade desapareceram (rotinas familiares, rotinas de férias, reunião com amigos, casamentos etc.) ou estão se transformando. Como disse, a vida imaginária mudou de sentido a partir do momento em que não possuíam mais o ethos e uma rotina ancorada no modo variguiano de ser. Desempregados, percebem que a sociedade vem a ser, ao mesmo tempo, mais complexa e mais ameaçadora. Descobrem que o domínio da vida se ampliou de maneira infinita e indefinida. Os conceitos que serviam para analisar uma realidade dominada pelo trabalho cotidiano, conhecido como mais querido e mais estável, não têm mais valor. A vida profissional deles, nesses mais de dez anos, somente pode ser apresentada como uma vida das mutações.

O aumento da desordem social e administrativa interna, o pouco apoio do governo, entre outros abandonos jurídicos e de representatividade, semearam entre eles, senão o esquecimento da VARIG próspera, a busca pelo afastamento de tudo que poderia prendê-los àquela derrocada. A VARIG, como legítima herdeira de uma empresa de bandeira nacional, suscitou mais regressões, contestações e insurreições do que solidariedade por parte do governo e da sociedade envolvente. Além disso, seus funcionários, na represa entre duas VARIG's - uma dona de um passado de glórias e outra esquecida -, entre dois mundos onde tentavam navegar, se defrontaram com a angústia do abandono e do esquecimento coletivo.
Nesse aspecto, provavelmente, há uma nova razão prática surgindo, plena de sua eficácia simbólica. Busco entender a mudança a partir dessas individualidades desconcertantes. Há uma determinante troca de verdade subjetiva por outra que demonstra novos meios de tomada de consciência da atual situação de mudanças de valores. Dessa forma, sugiro que as mudanças individuais e culturais na direção do esquecimento refletem as mudanças relacionadas às alterações sociais, políticas e econômicas, voltadas para um individualismo endêmico. Transformações contidas nos desencontros da globalização, no egoísmo individualista, na postura maniqueísta esquerda/direita. Em campo, são visíveis os sinais de descontentamento com o Ocidente globalizado. No caso da VARIG, os fatos de desordem estariam relacionados a uma situação global, econômica e social, marcada pelo afundamento do sistema de organização dos valores anteriormente compartilhados.

Os antigos valores rompidos eram derivados de uma monopolização orquestrada pela empresa, promovida e reproduzida por décadas no setor aéreo, por meio de simbolismo próprio. A efervescência de novos grupos, novas companhias a preços populares, baixos salários e serviços de transporte menos luxuosos produziu não só anomia, mas frustações. Uma nova ordem estabelecida caracterizou-se por uma necessidade fundamentada em movimentos globais e, portanto, naturalizados, de tal maneira que restou para alguns ex-variguianos buscar, como saída, o total afastamento da substância social anteriormente vivida.

Provavelmente, esse tipo de trajetória tem como objetivo estratégico a administração da própria fragilidade, por meio do afastamento e da 
negação da memória dos tempos vividos. Detectase, após mais de dez anos de sofrimentos e perdas, uma transição para outros modos de subjetivação. Na esteira das análises feitas por Lévi-Strauss (2008) sobre a eficácia simbólica, verifica-se que a verdade subjetiva de uma cultura dada é mais determinante para o processo humano (e mesmo para o processo médico) do que o objeto do qual se toma consciência. Trata-se, portanto, de viver uma nova ordem global e que passa necessariamente pela mudança e pelo esquecimento.

Se, antes, tinham as asas da liberdade e da eternidade inscritas no ethos variguiano de ser, fora da empresa, angustiados com a proposta de dar uma entrevista e repensar os papéis disparatados e desconexos que vivem, preferiram se afastar do tema. A entrevista, provavelmente, faz crescer ainda mais a angústia e o sentimento que voam sem asas, ou melhor, que voam agora só com uma asa. A asa dos direitos, que acreditavam jamais acabar, tinha desaparecido. Só resta agora se adaptar e aceitar que o que antes havia (salários altos, reconhecimento internacional, altos padrões de atendimento ao cliente etc.) não é mais uma realidade possível de existir nos tempos atuais, ditos modernos e globalizados. Pelo menos não no setor da aviação civil no Brasil.

$\mathrm{O}$ que cabe ressaltar, nesse ponto, é que, mesmo justificada - e, de certa forma, estando os funcionários convencidos das mudanças, aparentemente, necessárias e irreversíveis -, a segurança, alicerçada pelo antigo trabalho, é abalada.

O enfraquecimento das instâncias reguladoras no âmbito da aviação é algo pouco discutido socialmente; as mudanças na lei ocorrem sem a existência de um debate público explícito. Aqui, utilizo as reflexões de um autor que se transformou em referência sobre as metamorfoses da questão social mundial: Robert Castel (2001). Suas ideias não poderiam ficar de fora desta análise, pois muitos são os elementos concernentes aos fatos relacionados à precarização do trabalho no meio aviatório e ao abandono do ideário humanista diante da flagrante dispensabilidade de milhares de variguianos. De certa forma, o autor ajuda na consolidação de outra importante dimensão deste artigo, desta vez, na direção, inevitável, de uma crise da sociedade salarial. Ou melhor, na compreensão acerca da forma como o capitalismo atual vem encolhendo sociabilidades, ao excluir cada vez mais as pessoas das relações assalariadas. A falta de consideração, de seguridade, de bens garantidos e de vínculos estáveis configura o que Castel (2001:598) denomina como "individualismo negativo", tornandose parte do mal-estar contemporâneo, interpretado de modo mais amplo por alguns autores como uma crise da nossa própria civilização.

No Brasil, existe uma frágil concepção de responsabilidade pública em relação aos problemas sociais. No caso específico do trabalhador brasileiro, a partir da década de 1930 e da promulgação das leis trabalhistas, o Brasil passou a obedecer ao que Santos (1979) identifica como sendo uma "cidadania regulada", ou seja, uma cidadania concedida não ao indivíduo e com o caráter universal, mas apenas a algumas categorias sociais e ocupacionais regulamentadas dos assalariados urbanos. Ficam à margem, então, o setor informal, os trabalhadores rurais e, certamente, os setores terceirizados, sobretudo aqueles regidos pela nova lei voltada para o microempreendedor individual. Opção trilhada pela maioria dos ex-variguianos entrevistados na condição de prestadores de serviços. Como microempreendedor ou como terceirizado, a 
possibilidade de ser substituído a qualquer momento é facilitada, por não haver custos idenizatórios ao empregador.

Castel (2001) chama a atenção sobre a regulamentação que, no passado, constituiu uma identidade social para o trabalhador. Nos atuais processos de mudança, ao contrário, vive-se, segundo ele, a vulnerabilidade de "após proteções” (Castel 2001:593). Está em jogo uma nova regulamentação do trabalho, que vem sendo caracterizada pela falta de vínculos e pela ausência de suportes, somadas à substituição do trabalho humano pelo avanço tecnológico, afastando, portanto, qualquer referência ao coletivo, mesmo em relação aos profissionais da aviação brasileira, considerados por políticos e dirigentes de empresas aéreas como diferenciados na sociedade. Isso ocorre pelo menos no âmbito do discurso.

\section{MEMÓRIA E (RE)CONSTRUÇÃO DE IDENTIDADES PROFISSIONAIS}

Do próximo relato constante do Apêndice 2, busco mostrar, entre as dimensões já assinaladas, a experiência do individualismo negativo e do renascimento via a trajetória da ex-gerente de aeroporto da VARIG, ex-gerente regional e ex-gerente de aeroporto da Gol, com 49 anos; assim como analiso o quanto a sobrevivência e a perenidade ganham novo sentido e possibilitam a tomada de decisões, ou melhor, a busca pela sobrevivência entra em ação por meio da memória do antigo ofício. Esta personagem foi identificada nesta pesquisa como Zangolbireve.

O relato do Apêndice 2 contempla uma postura encontrada na análise das outras entrevistas e nas narrativas postadas em blogs: a luta para se manter vivo e renascido. O ressurgir das cinzas, tão bem caracterizado pelo mito de fênix, cuja simbologia representa a imortalidade e o reaparecimento cíclico (Chevalier \& Gheerbrant 1996:422).

Posso afirmar que os trabalhadores da extinta VARIG viveram e vivem momentos de transformação profunda. Permanecem em busca por novas formas de estar em atividade e produzindo o próprio sustento. Forçados, portanto, pela luta pela sobrevivência e para manter o padrão de vida que possuíam, eles se mantêm no incansável caminho da transição, do imprevisto. As representações e as imagens de si e da empresa relatadas não fogem a essa tendência, estando guardadas em suas memórias como fator importante para a vida atual.

O grupo de trabalhadores da VARIG pode ter sido o primeiro caso da nova Lei de Falência, porém, a meu ver, não se trata de um caso isolado. A anomia vista aqui como algo representado por manifestações incansáveis - que acompanham a difícil passagem de um gênero de atuação profissional degradado a outro que lhe sucede (mas ainda sem forma) - é similar aos acontecimentos sociais de transformação que estamos assistindo na sociedade brasileira. Esses processos de mudanças são justificados, nesse caso, pela globalização da economia e pelas novas e antigas narrativas sobre a modernidade.

A anomia vivida pelos variguianos foi experimentada, em 1966, pelos funcionários da Pan-Air do Brasil. A empresa foi fechada pela ditadura militar e envolvida em um processo fraudulento de falência, no qual seus extrabalhadores foram abandonados pelo Estado, nesse caso, em razão de a empresa e de seus 
dirigentes serem considerados inimigos dos desígnios ditatoriais da época. No caso da PanAir, diferentemente da VARIG, a anomia ocorreu por uma mutação repentina.

Nada fica no lugar quando uma empresa fecha suas portas e afasta todos do cotidiano e dos seus espaços vividos. Restaram para eles a memória de tempos compartilhados, bem como suas habilidades e conhecimentos adquiridos com o ofício de voar e de fazer voar. Mas o que fazer com os padrões culturais aprendidos? O que fazer com os seus projetos para a vida? A VARIG, como já foi dito, era uma empresa que apresentava um rumo certo: a aposentadoria. Era nascer, crescer, estudar, trabalhar e morrer. Todo o pacote incluído com a participação presente dos auxílios que a Fundação Ruben Berta proporcionava a todos. Sem esquecer o respeito pela necessidade, pela hierarquia do tempo de empresa, pelos cargos e salários e, por que não dizer, pela proximidade que o funcionário apresentava com a cúpula do poder executivo da empresa. A aposentadoria vinha como um lamento. Mesmo desvinculados profissionalmente do universo da aviação, é suficiente entrar em um aeroporto para que a postura técnica e a visão dos detalhes, imperceptíveis para o viajante comum, comecem a fazer sentido. A partir da observação desses sinais invisíveis, é possível ter acesso às informações somente acessíveis aos iniciados.

O espaço de um artigo é pouco para dimensionar a alteridade proporcionada pelo trabalho aéreo aos ex-variguianos. Ou, como já assinalado: "uma vez variguianos, para sempre variguianos". E saem por aí orgulhosos de ter participado de uma empresa tão importante para eles, que, infelizmente, segundo o ponto de vista deles, teve o próprio Estado como maior inimigo no final.

\section{CONSIDERAÇÕES FINAIS}

\begin{abstract}
Mas mesmo quando não restasse mais nada... além de máscaras vazias de sentido, pinturas incompreensíveis e danças sem objeto, não deixaria de ser certo que, para este povo, por detrás de todas essas formas e de todos esses ritmos, se esconde a sua vontade de durar, vontade que teve no momento em que, segundo os seus ditos, tomou consciência da decomposição da morte (Marcel Griaule).
\end{abstract}

Este artigo dividiu-se em duas dimensões de análise: a primeira, voltada para a compreensão da memória e das imagens simbólicas como totalidades representacionais, resistentes à separação do sujeito e do objeto. A imagem considerada igualmente como ativa, possuidora de um poder imediato de transformação daquele que a vê e, logo, a vive. Seja no trabalho, seja fora dele. A segunda buscou documentar etnograficamente os modos como o capitalismo, com dominância autoritária (Velho 2009:35), afirma-se e reafirma-se de modo insistente e proeminente na contemporaneidade. Buscou-se, aqui, trazer reflexões acerca da temática do trabalho precário, informal e, sobretudo, dos abandonos e das vulnerabilidades, seja por parte do Estado, no âmbito jurídico, representacional ou social, tendo como pano de fundo o esquecimento coletivo do grupo de antigos trabalhadores. 
Por meio da etnografia da trajetória de vida de ex-variguianos, foi possível demonstrar a crise da sociedade salarial, assim como o que vem se configurando como "individualismo negativo" (Castel 2001:598).

É notório, no contato com a pesquisa de campo, a influência de diversas imagens que obsidiam e modelam a vida psíquica e social daqueles que trabalhavam e dos que ainda trabalham no meio aeroviário. As formas de sociabilidades experienciadas através das referências às cerimônias, às festas, às reuniões informais, formadoras de sistemas de linguagem e de representações, proporcionaram a compreensão de como o conjunto dessas imagens ainda participa na construção da identidade do grupo e dos seus projetos para a vida.

O sentido que lhes é atribuído é proveniente de um considerável reservatório de imagens, marcado igualmente pela historicidade. A reflexão sobre o uso de imagens ligadas à ascensão e à mobilidade é importante, pois esclarece um conjunto de significados latentes. Contribui com a definição pluridimensional do ser humano no espaço social, com seus corpos, suas interioridades e sua ligação com o desejo de perenidade.

Fidelidade e fascínio formavam o elã necessário para conseguir colocar e manter no alto aquele objeto mais pesado do que o ar. E, por mais que entendamos os princípios da Física e da Aerodinâmica, quem, ao olhar um avião no céu, não se questionou do porquê de um objeto tão pesado conseguir voar? Atração e fascínio fazem parte deste universo. Um bom exemplo é verificar que aeroportos ainda são lugares atraentes de passeio, aonde pessoas vão para assistir o vai-e-vem das aeronaves no pátio, assim como para testemunhar seus pousos e decolagens.

Se o grupo de trabalhadores não estava preparado para ver o fechamento da empresa, de certa forma estava disposto a viver modificações constantes na medida em que elas ocorriam tanto na forma de procedimentos de trabalho como nas adaptações das regras mutantes do universo aéreo, onde a modificação é constante e veloz, e que escapam frequentemente à observação dos analistas políticos ou administrativos.

As formas de existência coletiva, apesar de tradicionais, como já foi realçado, eram modernas, no sentido, sobretudo, do novo. Além do mais, o regime por escala, com horários dos mais diversos, enchia de excepcionalidades a vida individual, que não se confundia com a vida de quem trabalhava com outros ofícios de horários fixos, com interrupções em finais de semana e feriados. Esses trabalhadores tinham uma rotina ou uma não rotina, como costumam dizer. A vida social era a mais afetada, de todas as dimensões. Se for possível falar de um ethos variguiano, este provavelmente estaria relacionado a uma heterogeneidade de modo de vida que o trabalho permitia, ou melhor, exigia de seus funcionários.

Com efeito, o pensamento auxiliado pelos mecanismos da memória encontra formas de achar continuidades em rupturas aparentemente permanentes. Logo, a memória vem como aquela que irá fazer a sutura dos novos sentidos da vida. Diante das necessidades e das disputas do presente, a memória das habilidades e seu potencial 
simbólico anteriormente utilizado no trabalho aeroviário vão se transformando como ferramentas estratégicas de resistência, por meio dela ou de sua negação. Em alguns casos, busca-se o reencontro com suas próprias capacidades de se colocar no mercado de trabalho e de encarar as mudanças.

A memória, nesse caso, transformou-se ao longo do tempo, de acordo com as necessidades de sobrevivência e de disputas do presente. Em alguns relatos, tornou-se um elemento de coesão e de orgulho, assim como forma de escapar do esquecimento e da morte. Trago para esta conclusão outro exemplo representativo da função fantástica do imaginário. As imagens levadas para as manifestações na frente do Tribunal de Justiça do Rio de Janeiro e nos movimentos públicos de reivindicação, realizados no ano de 2018, funcionam como promotoras de energia para enfrentar novos desafios. Uma delas, constante da Figura 2, era um boneco uniformizado, com uma máscara de caveira, representativa da morte. Um cartaz pendurado ao pescoço do boneco dizia: "Esperando Justiça VARIG”. Uma imagem que representa a morte do funcionário e a morte da empresa VARIG, à espera de justiça, mas, ao mesmo tempo, "afia em segredo as armas que abaterão o Dragão” (Durand 1997:288).

Esse tipo de representação, segundo análise durandiana, tem como função minimizar, dominar e afastar o perigo, sendo um adequado exemplo quanto ao poder metafísico do imaginário de erigir imagens que vão de encontro ao apodrecimento da morte e do destino. Para Durand (1997:288):

É aqui que transparece um princípio constitutivo da imaginação [...] figurar um mal, representar um perigo, simbolizar uma angústia, já é, pelo

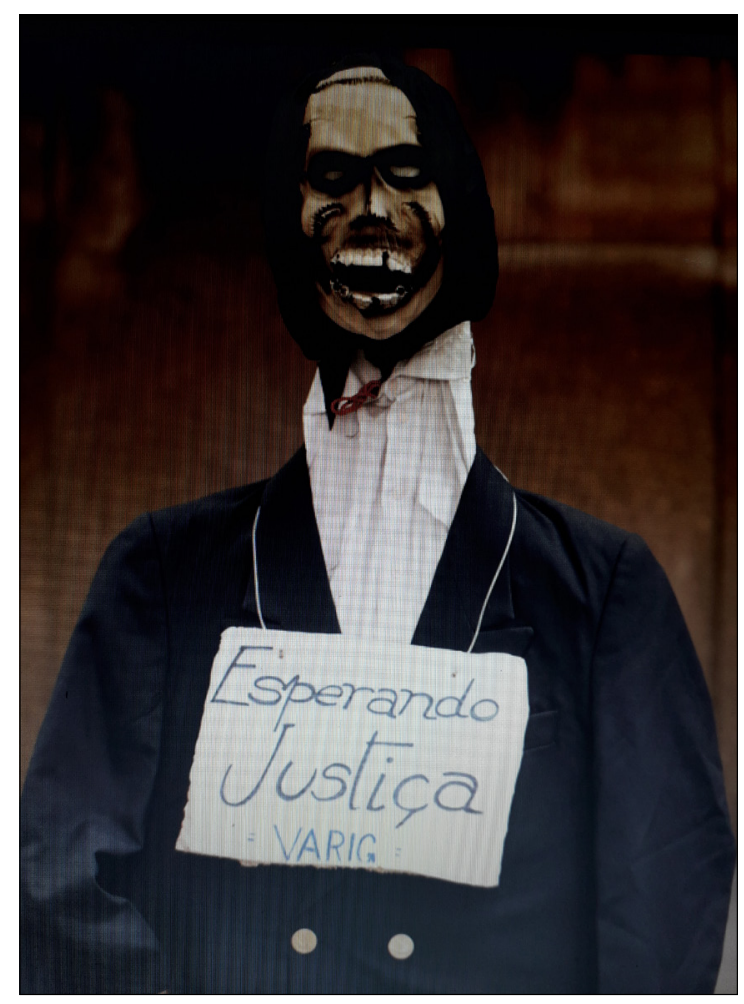

Figura 2 - Imagem que acompanha as manifestações públicas referentes à situação dos ex-funcionários da VARIG perante a justiça. Fonte: Melo \& Araujo (2018).

poder (maîtrise) do cogito, dominálos. Qualquer epifania de um perigo à representação minimiza-o, e mais ainda quando se trata de uma epifania simbólica. Imaginar o tempo sob uma face tenebrosa é já submetê-lo a uma possibilidade de exorcismo pelas imagens da luz. A imaginação atrai o tempo ao terreno onde poderá vencêlo com toda a facilidade. E, enquanto projeta a hipérbole assustadora dos monstros da morte, afia em segredo as armas que abaterão o Dragão.

Insisti em falar de memória, no caso VARIG, em grande medida porque ela própria, na busca da conservação e da sua manutenção, 
tinha como projeto interno e externo o uso da memória do passado da empresa como um meio de acúmulo a ser incorporado à consciência do presente. Com essa estratégia, buscava com que todos acreditassem que as normas internas da empresa, suas decisões, poderiam sempre dar respostas na direção das mudanças necessárias e, portanto, deveriam ser seguidas, apoiadas e respeitadas.

As pessoas envolvidas com esse trabalho viveram o mal-estar decorrente de uma democracia autoritária, que provocou a queda na crença da VARIG como una e indivisível. Foram obrigadas a viver uma dispersão explosiva. Com isso, assumem a essência cada vez mais personalista, característica das transformações em curso. Isso pode ser visto como resultado da maximização das responsabilidades da iniciativa individual, com a utopia de alcançar um modelo de humanidade capaz de se reciclar a cada instante para responder às exigências do mercado, de maior rentabilidade, eficiência e desempenho. O efeito mais evidente dessa transformação é uma nova rede de circulação de significados em termos de produção de subjetividades, voltadas para a aceitação das perdas como algo inevitável.

Por fim, com relação ao abandono do Estado, além do que já foi dito, é preciso registrar que nenhum variguiano sabe como foram feitos os cálculos de quanto a empresa deve a eles. O valor total de cada funcionário ainda na ativa, na época do fechamento, encontra-se em um site de acesso público, onde eles podem verificar o que receberão de salários atrasados e de direitos trabalhistas. Como a quantia foi calculada ou mesmo como questionar esses cálculos, ninguém sabe dizer ao certo. Todos os entrevistados apresentam um sentimento de revolta e de tristeza diante dessa situação por três motivos: 1) por não ter clareza do cálculo e não ter para quem apelar; 2) por ter seu nome e valores expostos para qualquer um que queira acessá-los; 3) por não saber quando e se receberão os referidos valores. Muitas são as limitações. Alguns ex-funcionários, por exemplo, não conseguiram dados sobre o valor do FGTS, por falta de informações completas do extrato analítico, sob a responsabilidade da Caixa Econômica Federal. Dessa maneira, não têm como calcular nem mesmo o valor da multa de $40 \%$, prevista em lei.

Enfim, diante do abandono e da perda de direitos garantidos pela lei, ficam felizes com qualquer quantia que ainda possam, de fato, receber. Apenas no dia 15 de outubro de 2018 , começou a ser pago o $2^{\circ}$ rateio parcial aos ex-funcionários, liberado pelo Judiciário. Uma média de cálculo realizada entre os que ainda estavam na ativa, por meio da soma dos valores recebidos dos dois rateios depositados, demonstra que o valor não alcança nem mesmo o percentual de $5 \%$ do devido, calculado e explicitado na web.

Praticamente abandonados à própria sorte, mais do que nunca, os antigos artífices desse trabalho precisam, para sobreviver, de renovados espaços representativos, sobre os quais eles possam se projetar e pelos quais eles possam ser saciados. Para além das necessidades básicas, desejos 
e tendências, carecem, como provavelmente diria Bachelard, de encontrar novos espaços de intimidade para continuamente renascer.

\section{AGRADECIMENTOS}

A pesquisa que resultou neste artigo contou com o financiamento da Fundação de Amparo à Pesquisa do Estado do Rio de Janeiro (FAPERJ). Este trabalho foi escrito durante o $2^{\circ}$ semestre de 2018 , como parte de minhas atividades como pesquisadora de pós-doutorado, no Programa de PósGraduação em Antropologia Social, do Museu Nacional, da UFRJ. Agradeço os comentários e as sugestões que José Sérgio Leite Lopes e Beatriz Maria Alasia de Heredia (in memoriam) ofereceram no Seminário de Antropologia do Trabalho, no qual apresentei algumas dessas ideias, permeadas de dúvidas e de expectativas. Agradeço à Danielle Rocha Pitta, eterna orientadora e estimuladora dos caminhos do imaginário. Uma primeira versão deste trabalho foi apresentada na $31^{\text {a }}$ Reunião Brasileira de Antropologia, realizada entre os dias 9 e 12 de dezembro de 2018, em Brasília, no Distrito Federal. Aproveito para agradecer as contribuições de Fernanda Valli Nummer, Maria Cristina Caminha de Castilhos França e Wilton Carlos Lima da Silva, que reforçaram a intenção em publicar essas reflexões. Agradeço aos pareceristas anônimos da Amazônica: Revista de Antropologia, pela leitura rigorosa e pelas sugestões esclarecedoras. Sou grata ao meu pai e a todos aqueles aeronautas e aeroviários, variguianos ou não, que fizeram parte desta pesquisa e me permitiram partilhar com amor do universo mítico do voo.

\section{REFERÊNCIAS}

Bachelard, G. 1976. A poética do espaço. Rio de Janeiro: Eldorado.

Bourdieu, P. 1989. O poder simbólico. Lisboa: Difel; Rio de Janeiro: Bertrand Brasil.

Bourdieu, P. 1998. A ilusão biográfica, in Usos e abusos da história oral. Organizado por M. M. Ferreira e J. Amado, pp. 183-191. Rio: Editora da FGV.

Brasil. 2005. Lei n. 11.101, de 9 de fevereiro de 2005. Regula a recuperação judicial, a extrajudicial e a falência do empresário e da sociedade empresária. Diário Oficial da União. Disponível em: http://www. planalto.gov.br/ccivil_03/_ato2004-2006/2005/lei/ 111101.htm. Acesso em: 18 fev. 2019.

Castel, R. 2001. As metamorfoses da questão social. 3. ed. Petrópolis: Vozes.

Chevalier, J., e A. Gheerbrant. 1996. Dicionário de símbolos. Rio de Janeiro: José Olympio.

Comte-Sponville, A. 1984. Le mythe d'Icare: traité du désespoir et de la béatitude. Paris: Presses Universitaires de France.

Durand, G. 1983. Mito e sociedade: a mitanálise e a sociologia das profundezas. Lisboa: A Regra do Jogo.

Durand, G. 1995. A fé do sapateiro. Brasília: Ed. Universidade de Brasília. 
Durand, G. 1997. As estruturas antropológicas do imaginário. São Paulo: Martins Fontes.

Durkheim, E. 1999. Da divisão social do trabalho. São Paulo: Martins Fontes.

Durkheim, E. 2000. Suicídio. São Paulo: Martins Fontes.

Duvignaud, J. 1973. Heresie et subversion: essais sur l'anomie. Paris: Anthropos.

Enriquez, E. 1997. A organização em análise. Rio de Janeiro: Vozes.

Geertz, C. 1966. A transição para a humanidade, in Panorama em Antropologia. Editado por S. Tax, pp. 31-43. Rio de Janeiro, São Paulo e Lisboa: Fundo de Cultura.

Geertz, C. 1978. A interpretação das culturas. Rio de Janeiro: Zahar.

Geertz, C. 1998. O saber local: novos ensaios em antropologia interpretativa. Rio de Janeiro: Vozes.

Lévi-Strauss, C. 2008. A eficácia simbólica, in Antropologia estrutural, pp. 265-291. São Paulo: Cosac Naify.

Lopes, J. L. 2011. Memória e transformação social: trabalhadores de cidades industriais. Mana 17(3):583-605. DOI: http://dx.doi.org/10.1590/ S0104-93132011000300004.

Mauss, M. 1974. Ensaio sobre a dádiva. Forma e razão da troca nas sociedades arcaicas, in Sociologia e Antropologia. Editado por M. Mauss, pp. 183-294. v. II. São Paulo: Edusp.

Melo, M., e S. Araujo. 2018. Calvário Linhas Aéreas: como bilionário calote trabalhista afetou a vida de milhares de ex-funcionários da VARIG, VASP e TRANSBRASIL. Disponível em: https://www. metropoles.com/materias-especiais/penuria-comosobrevivem-ex-funcionarios-de-varig-vasp-etransbrasil-2 Acesso em: 18 fev. 2019.

Morin, E. 1975. O enigma do homem: para uma nova antropologia. Rio de Janeiro: Zahar.

Nascimento, T. 2006. Demissões na VARIG somam 5.500. Diário de Pernambuco, 29 jul., Caderno Economia, p. B1, B2.

Pollak, M. 1989. Memória, esquecimento e silêncio. Estudos Históricos 2(3):3-15.

Ricoeur, P. 2007. O esquecimento, in A memória, a história, o esquecimento. Campinas: Unicamp.

Rodrigues, M. 2000. Investigando o imaginário entre aeronautas e aeroviários. Dissertação de Mestrado, Programa de Pós-Graduação em Antropologia, Universidade Federal de Pernambuco, Brasil.

Romeiro, T. 2014. O uso da Lei de Falências no caso VARIG. Tese de Doutorado, Programa de PósGraduação em Sociologia e Direito, Universidade Federal Fluminense, Rio de Janeiro.

Sahlins, M. 1979. Cultura e razão prática. Rio de Janeiro: Zahar. 
Santos, W. 1979. Cidadania e justiça: a política social na ordem brasileira. Rio de Janeiro: Campus.

Velho, O. G. 2009. Capitalismo autoritário e campesinato: um estudo comparativo a partir da fronteira em movimento. Rio de Janeiro: Centro Edelstein de Pesquisas Sociais.

Xausa, M. 1993. A importância das instituições e o desafio à liderança institucional. O caso VARIG.
Dissertação de Mestrado, Faculdade de Ciências Econômicas, Universidade Federal do Rio Grande do Sul, Porto Alegre.

Xerez, A. 2013. Mãe rampa: os impactos do encerramento do aterro metropolitano de Jardim Gramacho nos catadores de materiais recicláveis. Dissertação de Mestrado, Departamento de Antropologia, Universidade Federal Fluminense, Rio de Janeiro. 
APÊNDICE 1 - Trechos de entrevista realizada com um ex-funcionário da VARIG, identificado nesta pesquisa como Pertinvolzes, em 24 de outubro de 2018.

Eu entrei na VARIG em dezembro de 1988 e saí de lá em junho de 2006, que foi quando a VARIG faliu, né? [com tristeza na voz] Então foram quase 18 anos trabalhando na VARIG, como DOV. Essa foi a profissão que eu escolhi. Nunca tive nenhum tipo de talento para outra área, comercial, educacional, musical, artística, apesar de gostar muito de música. Mas foram quase dezoito anos exercendo a mesma função. Algumas vezes em estados diferentes e, muito eventualmente, em outros países. A falência da VARIG trouxe, né, um inusitado de uma realidade que eu não pensava, apesar da crise estar iminente e que se aproximava, com os salários parcelados, as pessoas muito emocionalmente abaladas, mesmo antes dela falir. Essa situação já se arrastava assim há uns três anos para você ter uma ideia! Mas, mesmo assim, eu acreditava que eu era - sei lá intocável pelo fato de eu ser um, por achar que eu era um padrão de profissional, né? Também por não acreditar no fim de uma empresa assim!

Mas eu percebi, então, que no momento que eu estava demitido que isso realmente não contava, não tinha que ser padrão, nem nada disso, na falência todos foram atingidos, né? [pigarro e pausa] Nós e a empresa, apesar de sua importância social.

Em termos financeiros, eu saí de lá sem receber nada.

A sorte - vou chamar de sorte - é que eu nunca tinha usado o fundo de garantia durante os dezoito anos e me vi com ele para me suprir durante um tempo e mesmo a esposa trabalhando - isso também me ajudou bastante - e aí a gente combinou que eu ia me preparar para um concurso público, estudar para isso, já que eu não queria ir para São Paulo, porque era o único mercado disponível na época. Então, eu ficava o dia todo estudando até que uns dois ou três meses depois eu fiquei sabendo que a ANAC tinha aberto um concurso e - coisa de Deus - pedia dois DOVS - tinha duas vagas para DOV.

Aí eu pensei: é a grande chance que eu tenho para ficar no Rio. Quando eu li o edital, eu vi que o salário era a metade do que eu recebia na VARIG, mas eu não achei isso tão ruim, pelo fato de eu ficar no Rio. Para mim já seria bom. Eu tomei posse no dia 3 de setembro de 2007, como técnico em regulação aérea, na atividade de DOV, pois lá tinham muitas outras profissões, piloto, engenheiro, muitas outras. $\mathrm{E}$ eu consegui uma dessas duas vagas de DOV que estavam dedicadas ao concurso.

Trabalho no grupo de exames teóricos desde que entrei. A partir de abril (2018), se eu quisesse ter me aposentado eu poderia ter me aposentado, ou seja, eu já consegui os requisitos mínimos para me aposentar, mas eu não quero me aposentar agora. Poderia me aposentar e continuar fazendo outra coisa, mas confesso a você que eu não me vejo correndo atrás de outro trabalho fora da aviação para tentar ganhar mais um pouco. Eu acho que na fase atual eu estou ganhando um salário que para o meu padrão e para as condições que eu tenho de conhecimento e de experiência, se não é o justo, mas para mim é o necessário. Então eu não tenho grandes ambições assim de ganhar um salário muito alto. 
Então, eu me sinto um privilegiado, confesso a você. Eu gosto muito de trabalhar lá, eu gosto muito do que eu faço. Apesar de nesses quase 29 anos ou mais na profissão eu não ter me desenvolvido dentro dessa área da aviação de uma forma mais, como é que eu vou te dizer, assim, mais brilhante, sei lá, de uma melhor forma, de não ter conseguido assim grandes progressos como profissional. É uma profissão técnica que eu não, não... Ao longo do tempo, se você não procurar se desenvolver você vai ficar nela a vida toda. O máximo que pode chegar numa empresa aí, depois de muito trabalho e depois de muita política! É uma gerência, é uma supervisão, assim, e depois uma gerência. Eu sequer consegui nos 18 anos de VARIG uma supervisão, mas aí já são outras histórias, né? Já é outra situação. Mas nunca fiquei, digamos assim, magoado por essas coisas, porque eu acho que depende muito de mim, eu não culpo ninguém de nada. Depende demais da minha, da minha, do meu desempenho, da minha procura, depende muito do que eu queira realmente da vida. E eu nunca fui muito ambicioso, isso é que é a verdade, nunca fiquei de olho ou, digamos assim, ou tentando conseguir graus maiores de sucesso. Eu nunca fui assim.

Eu vejo como ponto positivo, como eu falei, eu me sinto muito satisfeito. Existem essas situações de viajar para trabalhar que eu acho legal. Essa liberdade de ir e vir. Dá uma experiência boa. Um conhecimento maior. Eu tenho hoje, em relação há 20 anos atrás, uma mente mais aberta. Eu tenho uma disposição melhor. As pessoas que eu conheci agregaram a mim certos valores de vontade. De ter um pensamento positivo.

Mas mesmo com 60 anos de idade agora. É, eu deveria ter uma cabeça mais madura! Apesar de sessenta anos, às vezes eu tenho a impressão que eu não cresci. É como se eu estivesse ainda com 15 anos de idade. Pode parecer uma loucura, né? Mas às vezes eu acho isso. Eu resolvi agora estudar também, vou me inscrever na segundafeira, num curso à distância, curso de Ciências Aeronáuticas. É de uma Universidade do Rio Grande do Sul.

De positivo, nesse tempo todo, eu consegui melhorar minha autoconfiança, isso é que é a verdade. Me sinto mais confiante do que eu era há anos atrás. Eu não me preocupo mais com o futuro. Eu vivo os dias, eu vivo hoje, vou viver amanhã, e os dias vão passando e eu vou vivendo. Eu tenho mais coragem para fazer mais determinadas coisas. Apesar de eu falar que eu tenho, às vezes, essa impressão de ter 15 anos, mas também, às vezes, eu me olho e vejo que eu estou numa posição melhor tanto cronológica, como emocionalmente, eu acho.

$\mathrm{Eu}$ acredito que o tempo, ele tem sido bom comigo. Acho que eu sei, acho que eu aprendi a usar melhor o tempo. Esse tempo ele me favorece muitas vezes. Eu acho que a minha maior qualidade é a paciência, eu percebi já há um tempo, atrás, que essa minha serenidade, ela é, apesar de ser uma serenidade que se vê, que eu deixo transparecer, mas às vezes, por dentro, eu estou, digamos assim, muito agitado. Tanto é que em certas situações eu sou muito impulsivo. Eu sei que tenho que me controlar nessa parte. 
APÊNDICE 2 - Trechos de entrevista feita com uma ex-funcionária da VARIG, identificada nesta pesquisa como Zangolbireve, em 24 de setembro de 2018.

Entrei na VARIG em março de 1988, em Salvador. Eu vim do interior, Itabuna. Eu fui com uma leva para o aeroporto de 18 meninas, contrataram de vez. Aí, eu fui, entrei. Me botaram no check-in. Tinham aqueles que, como eu, queriam seguir carreira na aviação.

- E você saiu da VARIG?

Na verdade, eu não saí, né? Tipo assim, em 2006, você foi demitido da VARIG e contratado pela VRG S.A. Demitido num dia e contratado no outro, sei lá. Você só assinou o papel e continuou trabalhando.

O pessoal da SATA ${ }^{6}$ não tinha dinheiro para ir trabalhar. O povo perguntava, quem tem dinheiro? Eu tenho dez reais, então toma aí para você vir trabalhar. O pessoal vinha trabalhar por amor.

Olha a história. Eu já era gerente de aeroporto, em Recife. Ia fechar, eu estava trabalhando e eu tinha sessenta e poucos funcionários lá, em Recife. Sessenta e quatro. Aí o chefe liga e fala assim: eu preciso de uma lista com dez nomes, que são os que vão ficar. Você e mais dez, que vão ficar. Minha secretária ficou assim desesperada e eu falei: "calma, fica aí. Preciso de você inteira para me ajudar a me segurar".

- E hoje, como você está?

Depois eu te falo dos meus bicos, do que é que eu faço para ganhar dinheiro.

Se eu recebesse o dinheiro que tão me devendo, eu quitava meu apartamento. Com o dinheiro que eu ganho hoje, se eu não tivesse a dívida do apartamento, dava para eu ficar tranquila. Sem luxo, mas vivendo, né?
Eu só lembro o pessoal dizendo assim: "Ah, vai deixar a gente trabalhar o final de semana para depois demitir”. Alguns falavam, assim: "Ah, eu já não venho mais nesse final de semana”. Mas a maioria era muito comprometida, né? Vestiam a camisa. Não era nem vestiam a camisa. Estava no sangue.

Aí, quando chegou sábado de manhã, vamos para o aeroporto! Cheguei no aeroporto, chamei minha secretária, era de minha confiança e começamos a emitir as cartas. Tinha um menino, que era da segurança do trabalho, que disse: "eu também venho ajudar vocês". Ele ficou comigo. Aí eu comecei a demitir o povo do turno da manhã. Chegou o pessoal do turno da tarde, aí eu comecei a demitir o povo do turno da tarde. Aí, assim, aí eu comecei a passar mal. Aí o emocional, assim. E tendo de dizer. O que que eu ia explicar para as pessoas? Porque que eu não fiquei com fulano? E eram pessoas, e é uma família, gente que era arrimo de família, que era um salário que bem ou mal sustentava a casa. Só sei que teve uma hora que eu passei mal, a minha pressão baixou. Aí, o R. (o segurança do trabalho) veio com um copo de água. Ele trouxe um copo de água para mim. E eu disse, vamos lá, cara. Eu tenho que passar por isso.

Aí, fiquei com dez pessoas. E como é que trabalhava? Tinham os horários, tinham os turnos. Eu só sei que um menino falou assim: "mas quem é que vai vir amanhã de madrugada?". Eu falei: "não sei, eu venho”. E ele, “não! Eu venho”. Eu vou

6 A Serviços Auxiliares de Transportes Aéreos (SATA) também foi uma empresa do Grupo VARIG. 
assinar hoje a demissão, mas eu venho. Ele veio trabalhar demitido.

Quando virou VRG S/A, e aí começou a voltar uns voos, o primeiro que chamei foi ele. Aí, chamei, Maria da loja. Maria hoje está vendendo roupa. Numa lojinha lá em Jaboatão.

Aí ficamos com a história do chinês. Aí depois teve o zum, zum, zum da GOL. Ah, a GOL comprou a VARIG. Aí já foi em 2007. E eu fui a primeira a ser transferida da VARIG para a GOL, no Brasil todo, de aeroporto. E tinha um detalhe, a VARIG pagava um salário bom, né? A GOL pagava um salário merreca. E eu fui transferida para o Galeão. E eu lembro que quando cheguei lá me falaram: "você ganha muito mais que o ex-gerente da GOL”. Quiseram baixar meu salário, mas não conseguiram por se tratar de transferência. Eu disse: "Me transferiram para cá para eu ganhar o mesmo salário”.

E olha lá, quando eu me candidatei para ser supervisora de turno no Galeão pela VARIG, o trabalho como gerente era dez vezes, muito maior. Então, quando eu me candidatei, o salário era 50\% maior do que o de gerente de aeroporto em Recife.

Eu acho que uma das coisas que eu acho que deve ter quebrado a VARIG também eram esses salários muito altos ${ }^{7}$.

O fechamento da VARIG foi usurpador, foi agressivo.

Porque depois que eu entrei na aviação, eu me fascinei assim. Comecei a encarrar como uma carreira, comecei a estudar, comecei a buscar a legislação, coisa que ninguém ia assim. Na época, não existia faculdade de aviação civil, não existia.

Hoje, eu não tenho vergonha do meu trabalho. Eu não tenho, graças a Deus, eu não tive problema com isso. Tipo, ah, eu fui uma gerente da VARIG, hoje eu não sou. Hoje, eu não tenho nenhum cargo. Sou super de boa com isso. Me viro. Eu foco a minha energia em outra coisa. Olha só. Vamos! Eu tenho apartamento para pagar, tem filho para dar de comer, muita coisa para curtir e vamo que vamo.

Mas é muita história. A gente hoje tem um grupo do pessoal de Salvador e volta e meia todo mundo marca encontros, o pessoal de Brasília, tipo assim, eu vou a encontros de todas as bases que eu já trabalhei. Até hoje, nós temos um vínculo que ninguém consegue explicar. Esse grupo tem um menino que trabalha em Barcelona que foi do meu turno. Tem uma menina que mora em Mônaco que foi do meu turno [...]. Então, tipo assim, o grupo está com pessoas espalhadas no mundo inteiro e todo mundo tem aquele carinho, tem aquela lembrança. Aquele carinho. Volta e meia manda fotos antigas da época da VARIG. É em qualquer lugar. Eu tenho um grupo de amigos de Recife, da VARIG de Recife, tenho um grupo de amigos da VARIG de Brasília. Eu, graças a Deus, tive essa experiência em três cidades.

Na VARIG, eu gostava desse sentimento de orgulho de trabalhar nela. Toda viagem que a gente fazia no exterior, a gente queria ir na loja

7 Em valores nominais, no momento em que se candidatou à vaga, em 2002, o salário de gerente de aeroporto da VARIG, no Recife, era de aproximadamente R $\$ 5.000$ mil, e um supervisor de turno, com menor responsabilidade do que um gerente de aeroporto, no Galeão, já ganhava R\$7.500,00. Caso a ex-variguiana viesse a trocar a gerência de aeroporto, do Recife, pelo cargo de supervisão, no Galeão, acumularia ainda mais R\$1.000,00 de adicional de antiguidade. Ou seja, a VARIG, além de respeitar as diferenças de custo de vida e de quantidade de trabalho entre as cidades brasileiras, fazia acréscimos no salário por antiguidade. 
da VARIG. Paris, Portugal, Nova Iorque. Eu tenho foto minha na loja da VARIG em Bangkok, que doideira, lembrar disso agora, que eu fui na loja da VARIG em Bangkok, Nossa Senhora. A gente estava voltando de Bali. Na época, eu fui com meu ex-marido, que também trabalhava na VARIG.

Com a VARIG já em crise, eu vim fazer uma entrevista numa empresa de helicóptero e me chamaram, eu estava em Recife, mas eu não fui, eu disse, eu sei que a VARIG está ruim, mas eu resolvi apostar ainda na VARIG. Ia trabalhar em Macaé, com transporte para a Petrobras. Fui só testar minha empregabilidade.

Depois que eu fui para a GOL, fiquei de 2007 até 2013. Eu fui gerente de aeroporto, depois virei gerente regional, aí também gerenciava bases no exterior, gerenciava bases na Bolívia e na República Dominicana.

Foi muita ralação, sofri muito naquele Galeão. Eu cheguei a ficar 36 horas trabalhando no Galeão uma vez.

Depois, uma amiga que foi demitida no mesmo dia que eu, da GOL, me falou: "olha, o pessoal da Copa está contratando para trabalhar na Copa do Mundo, para coordenar os voos nos aeroportos. Tem em Cuiabá, Porto Alegre e Natal”. Disse: "vou para qualquer lugar”. Passada uma semana ela ligou: "Amiga, você vai para Manaus". "Mas, como assim, você não vai para Manaus?”. Não, eu desisti! "E você vai ficar na casa de minha tia. Eu vou te levar lá. Eu pego um voo aqui de São Paulo e você aí do Rio e vou te entregar para ela”. Foi ótimo! Seis meses de trabalho.

Voltei e vamos procurar emprego. Fiquei agosto e setembro, quando foi final de agosto, início de setembro, fiz uma entrevista de seis etapas para ser gerente de uma escola em Nova Iguaçu. Salário de R 8 mil reais. Aí, aceitei e passei seis meses em Nova Iguaçu. Curso de mídias eletrônicas. Cuidava da manutenção da escola, dos professores, da administração da escola. Foi de outubro a março, aí me ligam para eu trabalhar nas Olimpíadas. Aí, eu estou na escola e me ligam, o pessoal da turma de eventos, que é uma mesma panelinha. Aí, me ofereceram R\$ 9 mil e 500 e eu saí da escola, mesmo sabendo que era por tempo determinado. Resolvi arriscar. Pedi as contas na escola. Me identificava com o trabalho. Fiquei um ano e meio nas Olimpíadas. Me acabei, passei por vários perrengues também. Aprendi muito. Uma galera muito doida, mas sobrevivi.

Aí terminou as Olimpíadas, o Rio de Janeiro faliu. Ferrou. Aí, de outubro de 2016, fiquei no seguro desemprego. A minha síndica, que trabalhou na VARIG, perguntou se eu não queria trabalhar na secretaria para ajudá-la a administrar o prédio, nas férias da funcionária. Me pagando em RPA. Aceitei. Ela e o marido trabalharam na VARIG. Aí, a menina voltou das férias, mas a outra menina que trabalhava com ela pediu demissão. Aí a sindica me chamou novamente. Me fez a proposta de não assinar a carteira e pagar como Pessoa Jurídica. Aí, eu fiz o microempreendedor individual e, mesmo sabendo que o recolhimento da aposentadoria só pode ser no valor de um salário mínimo, aceitei. Cuido de toda parte de orçamento, condomínio e compras.

Rola uns bicos, a gente faz trocentos bicos aí. E vamos vivendo.

Eu provei que eu, apesar da expertise na aviação, eu posso administrar qualquer coisa. Eu 
posso administrar uma escola, uma vila olímpica, que eu era responsável pelo transporte, todos os atletas que entravam eu era gerente geral de transporte, da vila, dos atletas. Então, o que rolar aí vamos ter que encarar.

A aviação tem esse poder. A memória é muito forte daquele tempo. Tipo assim, a VARIG me abriu o leque do mundo. Eu não tinha ideia da dimensão do mundo antes de entrar na VARIG. Eu acho que não é um emprego qualquer trabalhar na aviação. Mesmo hoje em dia, que já perdeu um pouco o glamour. Trabalhar na aviação é assim... [pausa longa] Vou dizer que eu não sinto saudade? Eu sinto saudade, foi quase uma vida inteira, foram 19 anos de VARIG, mais seis de GOL. Mais de vinte e cinco anos de vivência de aeroporto. Quando a VARIG começou com a crise, eu tinha, todos os meus amigos eram fãs da VARIG. Tipo assim, pros meus amigos que não eram da aviação isso era um must, para a família, para os amigos, nossa! A aviação abriu o leque do mundo. Mas eles agora falam assim: "cara, mas você trabalhou sua vida inteira na aviação, se eu até para te indicar para outro emprego, o que você sabe fazer?". As pessoas tinham muito isso também. E eu dizia: "oh, cara, a pessoa só porque trabalhou no aeroporto, essa pessoa pode trabalhar em qualquer lugar!”. Você tem uma escola de vida, né? De tudo, do que você pode fazer. Tudo o que você encarou no Galeão. Você encontra todo tipo de pessoa, tanto de passageiro quanto da equipe, como autoridades aeroportuárias. Você lidar com Polícia Federal, com Receita Federal, não é? Então eu lembro uma vez, em Salvador, que o cara me deu voz de prisão no dia de Natal. Ele disse: "você quer que eu te prenda?". Eu respondi: "você faz o que você achar melhor”. Eu já abri malas com drogas, com ouro. Eu já peguei um paletó que um passageiro esqueceu no avião com vinte e cinco mil dólares em notas de cem. Eu devolvi. Então, a aviação tinha essa coisa. Eu conheci o mundo. Criança, meu sonho era ir para Disney. Então, nas primeiras férias internacionais, eu fui para Disney. Levei minha mãe, levei minha tia. Então, eu acho que foi tudo na época certa. Foi muito bom. Foi bom enquanto durou. Então se tiver que voltar eu volto. Encaro. É como dizem hoje. Ah, são os órfãos e viúvas da VARIG. Mas tudo que a gente viveu não tem preço. Ano passado nós fizemos um encontro em Salvador, no hotel da Bahia, no Tropical, que era do grupo VARIG, do pessoal de Salvador. E eu peguei uma passagem e fui só para esse encontro. Só para ir nessa feijoada. Então, tinham mais de oitenta pessoas de todos os setores da VARIG de Salvador. Todo mundo feliz! E todo mundo contava os causos e foi uma tarde inteira, a gente fechou o restaurante do hotel. Ficou a tarde inteira e todo mundo relembrando as histórias. E não era barato. Foi novembro de 2017. Fizeram até as bolas para comemorar os noventa anos da VARIG. E a gente organizou o encontro num final de semana. Olha a foto da galera! 